\title{
Chapter 8 \\ Dietary Exposure to Additives and Sorbed Contaminants from Ingested Microplastic Particles Through the Consumption of Fisheries and Aquaculture Products
}

\author{
Esther Garrido Gamarro and Violetta Costanzo
}

\begin{abstract}
Microplastics and nanoplastics may be found in the gastrointestinal tract of some aquatic animals and could potentially be ingested by humans if consumed whole. Information on the toxicity of plastic particles, as well as co-contaminants such as plastic additives, remains scarce. This represents a serious challenge to perform realistic risk assessments. An exposure assessment of selected plastic additives and co-contaminants of known toxicity associated with microplastics was carried out for shellfish in this study, which builds on an exposure assessment of microplastic additives and a limited number of associated contaminants in mussels conducted by the FAO in 2017 . This study evaluates possible impacts to food safety by examining a diverse additives and associated sorbed contaminants. The results suggest that the levels of certain microplastic additives and sorbed co-contaminants in target animals (shrimp, prawns, clams, oysters, and mussels) do not pose a food safety threat to consumers. To get to further conclusions, an exposure assessment from the whole diet should be carried out and the toxicity of some of the most common polymers and plastic additives, as well as their mixtures, needs to be carefully evaluated.
\end{abstract}

\subsection{Introduction}

Plastic production has been increasing exponentially since the 1950 s and was estimated to be 8300 million metric tons to date (Geyer et al. 2017). Since its first development in the $1800 \mathrm{~s}$, the production of plastic materials has changed to meet the needs of a variety of sectors and consumers and has enabled technological improvements and solutions. Due to their functional properties ("cheap and

E. Garrido Gamarro $(\bowtie) \cdot$ V. Costanzo

Fisheries and Aquaculture Division, Food and Agriculture Organization of the United Nations (FAO), Rome, Italy

e-mail: esther.garridogamarro@fao.org

M. S. Bank (ed.), Microplastic in the Environment: Pattern and Process,

Environmental Contamination Remediation and Management,

https://doi.org/10.1007/978-3-030-78627-4_8 
durable"), plastics have displaced many non-plastic materials, becoming the most utilized materials worldwide.

Plastics consist of a range of synthetic or semi-synthetic chemicals that are made of fossil resources and organic by-products. They are commonly divided into three categories: thermoplastics (polymers that can be re-melted), elastomers (elastic polymers that return to their original shape after being deformed), and thermosets (polymers that remain in a permanent solid state once hardened).

Depending on their specific use, polymers with different physical and chemical properties can be mixed and additives such as plasticizers, colourants, UV-stabilizers, flame retardants, and antioxidants can be added to improve the performance of the final product.

Recycling the complex mixtures of chemicals used for plastic production can be challenging, as well as the evaluation of their impact on the environment and human health. The extensive production of plastic requires efficient waste management systems, but most countries do not have the capacity to develop them.

Microplastic particles have been found in a variety of human food items, such as salt, beer, honey, and aquatic products, with seafood being the best-studied source of dietary intake of microplastics. Exposure to microplastic particles, their additives, and their sorbed co-contaminants depends on several factors, such as particle size, shape, chemical changes that occurred during processing and/or cooking of fisheries and aquaculture products, and consumption patterns.

A previous study on exposure to microplastics and associated co-contaminants suggests that exposure to this contaminant burden is typically less than $0.1 \%$ (FAO 2017). Microplastic contribution to the total dietary intake of additives and sorbed co-contaminants was estimated as very low, with maximum increases in BPA, PAHs, and PCBs load of less than 2\%, $0.004 \%$, and $0.006 \%$ respectively, after the ingestion of a portion of mussels (EFSA 2016). However, a recent study by Barboza et al. (2020) observed a clear correlation between microplastics intake in three species of wild-caught commercial fish and the levels of bisphenols in the muscle and liver. Higher microplastic concentrations in fish were correlated with higher levels of these compounds, whose concentration in the edible tissue exceeded the established limits for human safety set by the EFSA. Furthermore, a relation between the concentration of plastic-associated chemicals and ingested microplastics in marine organisms has already been hypothesized (Granby et al. 2018; Rochman et al. 2013; Teuten et al. 2009). These findings suggest that more investigations should be conducted on this subject to better identify the role of microplastics in the transfer of pollutants and which factors could influence the process. This chapter aims to provide an overview of the dietary exposure of microplastic particles, additives, and common microplastic co-contaminants through aquatic products using consumption data from the FAO/WHO database, while information on contamination levels of plastic pellets and microplastic ingestion by seafood are updated with the current literature. Moreover, four different groups of seafood were considered, to extend the exposure evaluation also to crustaceans and other bivalves. The final estimations are compared with the no observed effect levels (NOELs) and no observed adverse 
effect levels (NOAELs) and can be useful to provide a better understanding of the potential impacts on food safety.

\subsection{Sorption of Environmental Contaminants by Microplastics}

A potential threat to human health deriving from the exposure to microplastics is that these materials can scavenge and thus concentrate pollutants already present in production waters. The ingestion of contaminated plastic could lead to higher exposure to toxic chemicals, with possible endocrine disruption and carcinogenicity. The main process leading to the interaction between microplastics and hydrophobic organic chemicals (HOCs) in the water column does not involve the formation of covalent bonds; thus, its reversible nature preserves the likelihood of chemical desorption from the matrix (Endo and Koelmans 2016). Besides, plastic polymers are also recognized as possible vectors of heavy metals in the marine environment (Holmes et al. 2012, 2014), being experimentally able to accumulate concentrations even 800-fold higher than in seawater (Brennecke et al. 2016). Many field studies such as the International Pellet Watch have reported the concentration levels of persistent organic pollutants (POPs) and metals sorbed on beached and marine pellets, in addition to plastic additives (Tables 8.1 and 8.2).

Sorption processes can be classified into adsorption and absorption, depending on the mechanism of interaction between the polymer and the chemicals. Absorption mainly occurs when the molecules of pollutants diffuse into the bulk matrix of the polymer and interact with it through weak van der Waals forces or hydrophobic interactions. This process is mainly driven by the preferential partitioning of the chemical on plastic compared to water, which is usually linearly and positively correlated to its octanol-water partition coefficient $\left(\mathrm{K}_{\mathrm{ow}}\right)$, a parameter that measures the level of hydrophobicity (Lee et al. 2014; Li et al. 2018c; O'Connor et al. 2016). Adsorption refers to a process that results in the sorption of molecules that are confined to the surface of microplastics (Endo and Koelmans 2016).

Absorption mainly occurs onto rubbery polymers (i.e. PE and PP), where external molecules pass through and associate within their matrix (Hüffer and Hofmann 2016; Müller et al. 2018; Teuten et al. 2009; Wang et al. 2018a). These polymers are generally recognized as the ones concentrating the highest amounts of HOCs and are then possibly more dangerous for marine life (Endo et al. 2005; Fisner et al. 2017; Hirai et al. 2011; O'Connor et al. 2016; Wang and Wang 2018; Wang et al. 2018b) and possibly human health.

Some polymers present several functional groups on their surface, conferring a certain degree of polarity. These are mostly PS and PVC, whose glassy nature also yields the formation of nanovoids and pores on the surface, which are the sites of sorption. In this case, the process is mainly led by adsorption, a mechanism through which the chemicals more efficiently bind to the plastic polymer through ionic, 


\begin{tabular}{|c|c|c|c|c|c|c|c|c|c|c|c|}
\hline 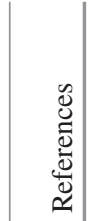 & 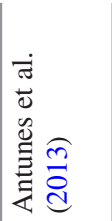 & 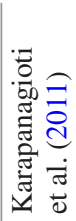 & 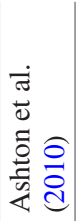 & 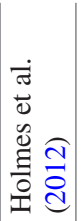 & 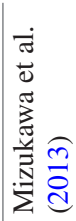 & 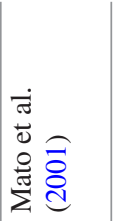 & 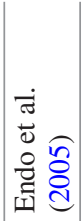 & 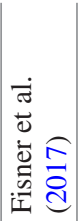 & 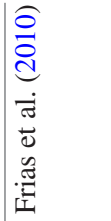 & 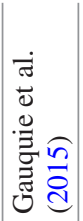 & 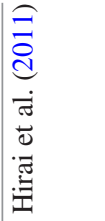 \\
\hline$\frac{0}{0.00}$ & $\stackrel{\stackrel{\Im}{\hookrightarrow}}{\leftrightarrows}$ & 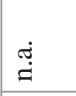 & $\stackrel{\infty}{\circ}$ & $\stackrel{+}{0}$ & 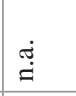 & $\stackrel{\stackrel{\leftrightarrow}{~}}{=}$ & $\stackrel{\overbrace{}}{\hookrightarrow}$ & $\stackrel{\overbrace{}]}{g}$ & $\stackrel{\overbrace ্}{=}$ & $\stackrel{\overbrace ্]}{=}$ & $\stackrel{\stackrel{\leftrightarrow}{\hookrightarrow}}{=}$ \\
\hline$\overline{0}$ & $\stackrel{\stackrel{f}{த}}{=}$ & $\stackrel{\stackrel{\overbrace{}}{~}}{=}$ & 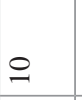 & ڤ̊ & $\stackrel{\stackrel{\leftrightarrow}{~}}{=}$ & $\stackrel{\stackrel{\leftrightarrow}{=}}{=}$ & $\stackrel{\stackrel{\Im}{த}}{=}$ & 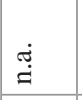 & $\stackrel{\stackrel{\leftrightarrow}{\dot{~}}}{ }$ & $\stackrel{\stackrel{\overbrace{}}{二}}{=}$ & $\stackrel{\stackrel{\leftrightarrow}{=}}{=}$ \\
\hline 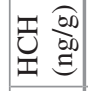 & $\stackrel{\stackrel{\leftrightarrow}{\hookrightarrow}}{=}$ & $n$ & 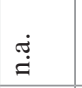 & 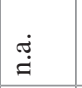 & $\stackrel{m}{m}$ & 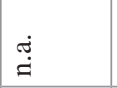 & $\stackrel{\stackrel{\overbrace{}}{=}}{=}$ & ঙ્ & $\stackrel{\stackrel{\leftrightarrow}{=}}{=}$ & 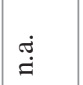 & $\stackrel{\stackrel{\leftrightarrow}{=}}{=}$ \\
\hline 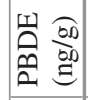 & $\stackrel{\overbrace ্}{=}$ & 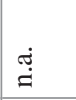 & 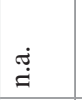 & $\stackrel{\overbrace{}}{=}$ & $\stackrel{\stackrel{\Im}{\hookrightarrow ~}}{=}$ & $\stackrel{\stackrel{\Im}{\hookrightarrow}}{=}$ & $\stackrel{\stackrel{J}{\leftrightarrows}}{=}$ & $\stackrel{\stackrel{\leftrightarrow}{\hookrightarrow}}{=}$ & $\stackrel{\stackrel{\oplus}{த}}{9}$ & $\stackrel{\stackrel{\leftrightarrow}{\hookrightarrow}}{=}$ & ஓे \\
\hline 领 & & $\bumpeq$ & $\stackrel{\stackrel{J}{g}}{=}$ & $\stackrel{\overbrace{}]}{g}$ & $\stackrel{\stackrel{\leftrightarrow}{\leftrightarrows}}{=}$ & $\vec{m}$ & 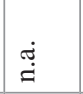 & $\stackrel{\stackrel{\leftrightarrow}{\hookrightarrow}}{=}$ & $\begin{array}{l}\infty \\
0 \\
0\end{array}$ & $\stackrel{\stackrel{\leftrightarrow}{\sharp}}{=}$ & $N$ \\
\hline 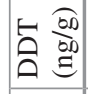 & $\bar{F}$ & $\stackrel{\text { F }}{*}$ & 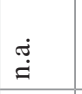 & 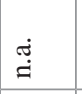 & g) & $\stackrel{\stackrel{\overbrace{}}{=}}{=}$ & $\stackrel{\stackrel{\leftrightarrow}{\leftrightarrows}}{=}$ & $\stackrel{\stackrel{\leftrightarrow}{g}}{=}$ & $\stackrel{+}{\sim}$ & $\stackrel{\stackrel{\leftrightarrow}{=}}{=}$ & $\stackrel{\infty}{+}$ \\
\hline 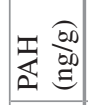 & $\begin{array}{l}8 \\
\infty \\
\dot{f} \\
\end{array}$ & 8 & $\stackrel{\stackrel{\leftrightarrow}{\dot{g}}}{ }$ & 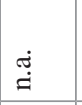 & $\begin{array}{l}8 \\
8 \\
0 \\
i \\
i\end{array}$ & $\stackrel{\stackrel{\overbrace{}}{~}}{=}$ & $\stackrel{\stackrel{\leftrightarrow}{=}}{=}$ & $\begin{array}{l}\text { है } \\
\text { लें }\end{array}$ & $\begin{array}{l}0 \\
\stackrel{0}{m}\end{array}$ & $\begin{array}{l}\hat{\delta} \\
\text { d }\end{array}$ & $\begin{array}{l}\infty \\
\infty\end{array}$ \\
\hline 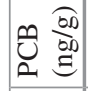 & 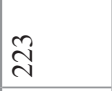 & ঐ) & 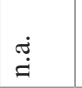 & $\stackrel{\overbrace{}}{g}$ & $\frac{\circ}{m}$ & $\Xi$ & $\begin{array}{l}8 \\
\text { } \\
\text { N }\end{array}$ & $\stackrel{\stackrel{\overbrace{}}{=}}{=}$ & in & $\stackrel{\sim}{\sim}$ & $\stackrel{\infty}{\sim}$ \\
\hline 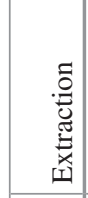 & 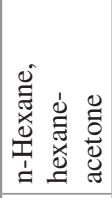 & 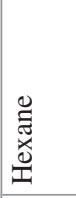 & 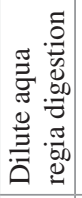 & 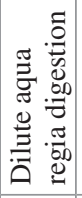 & 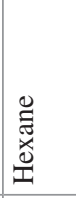 & 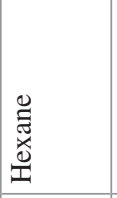 & 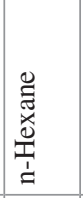 & 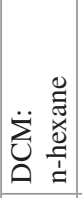 & 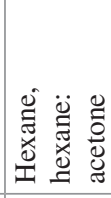 & 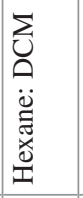 & 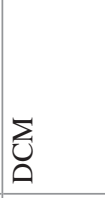 \\
\hline 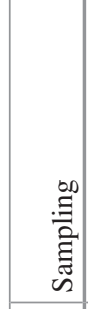 & 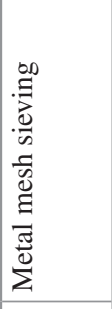 & $\begin{array}{l}\dot{y} \\
z\end{array}$ & 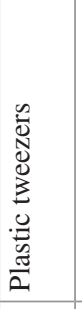 & 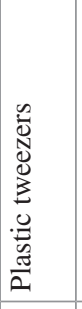 & $\begin{array}{l}\dot{y} \\
z\end{array}$ & 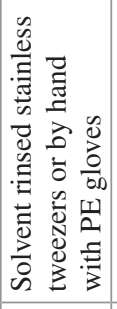 & 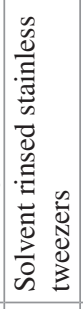 & 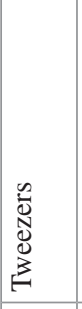 & $\begin{array}{l}\dot{y} \\
\dot{z}\end{array}$ & $\begin{array}{l}\dot{y} \\
z\end{array}$ & 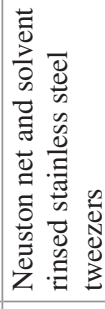 \\
\hline 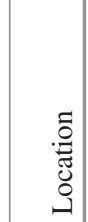 & $\begin{array}{l}\vec{y} \\
\tilde{0} \\
0 \\
0 \\
0 \\
0 \\
0 \\
0 \\
\overrightarrow{0} \\
0 \\
0\end{array}$ & 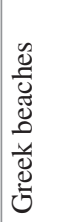 & 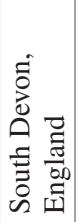 & 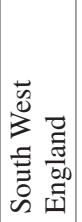 & 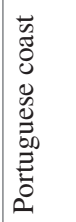 & 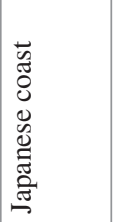 & 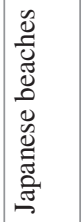 & 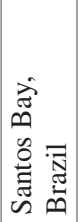 & 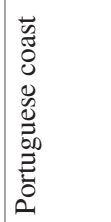 & 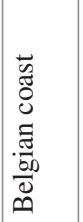 & 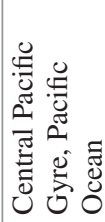 \\
\hline
\end{tabular}


8 Dietary Exposure to Additives and Sorbed Contaminants from Ingested...

\begin{tabular}{|c|c|c|c|c|c|c|c|c|c|c|}
\hline 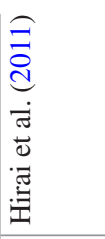 & 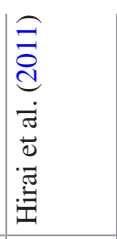 & 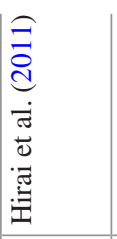 & 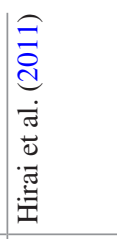 & 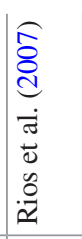 & 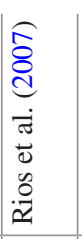 & 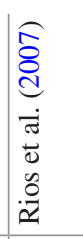 & 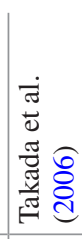 & 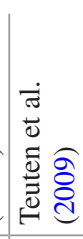 & 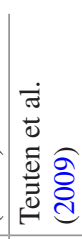 & 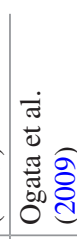 \\
\hline 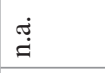 & $\stackrel{\stackrel{\Im}{\leftrightarrows}}{=}$ & $\stackrel{\overbrace{}}{\dot{g}}$ & $\stackrel{\stackrel{\Im}{\leftrightarrows}}{9}$ & 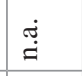 & $\stackrel{\Im}{=}$ & 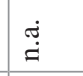 & $\stackrel{\stackrel{\oplus}{g}}{=}$ & $\stackrel{\overbrace{}}{g}$ & $\stackrel{\overbrace ্}{g}$ & 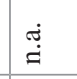 \\
\hline$\stackrel{\overbrace{}]}{\leftrightarrows}$ & $\stackrel{\stackrel{\Im}{\leftrightarrows}}{=}$ & $\stackrel{\overbrace{}}{=}$ & $\stackrel{\stackrel{\leftrightarrow}{\leftrightarrows}}{=}$ & 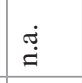 & $\stackrel{\stackrel{\Im}{~}}{=}$ & 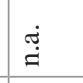 & 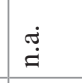 & 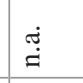 & 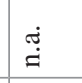 & 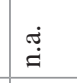 \\
\hline$\stackrel{\overbrace ্]}{=}$ & 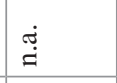 & $\stackrel{\overbrace{}}{=}$ & 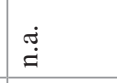 & 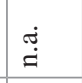 & $\stackrel{\overbrace{}}{=}$ & 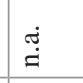 & 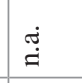 & 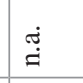 & $\stackrel{\overbrace ্}{=}$ & $\stackrel{\overbrace{}}{\simeq}$ \\
\hline તె & $\frac{\gamma}{2}$ & 尹 & $\stackrel{\infty}{-}$ & $\stackrel{\overbrace ্}{\dot{g}}$ & $\stackrel{\stackrel{J}{\leftrightarrows}}{=}$ & 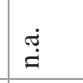 & $\stackrel{\stackrel{⿹}{\leftrightarrows}}{\leftrightarrows}$ & $\vec{i}$ & in & 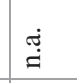 \\
\hline$\stackrel{\varrho}{\varrho}$ & F & $\stackrel{0}{r}$ & 잉 & $\stackrel{\stackrel{\Im}{\leftrightarrows}}{=}$ & $\stackrel{\stackrel{\Im}{\dot{g}}}{=}$ & 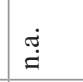 & $\stackrel{\text { Iேj }}{=}$ & $\stackrel{0}{\stackrel{0}{2}}$ & $\stackrel{r}{\dot{\gamma}}$ & $\stackrel{n}{=}$ \\
\hline$\stackrel{2}{\varrho}$ & $\stackrel{\infty}{\varrho}$ & $\infty$ & $\stackrel{\Xi}{\beth}$ & ป & $\stackrel{\overbrace ্}{=}$ & $\stackrel{8}{\varrho}$ & $\stackrel{\stackrel{\oplus}{\leftrightarrows}}{=}$ & $\stackrel{\overbrace{}}{\text { பே }}$ & $\stackrel{\overbrace{}}{=}$ & 6 \\
\hline ลે & ત્ડ & ஜn & $\underset{\sim}{+}$ & in & 앙 & ஓ్ర్ర & $\stackrel{\check{J}}{=}$ & $\stackrel{2}{2}$ & ฉે & $\stackrel{\overbrace{}}{\check{~}}$ \\
\hline 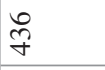 & ᄋ̊ & হু & $\overline{6}$ & $\stackrel{\triangleright}{\circ}$ & $\stackrel{\overbrace{}}{\stackrel{\leftrightarrow}{\leftrightarrows}}$ & $\stackrel{尺}{\curvearrowright}$ & $\stackrel{\alpha}{\infty}$ & 点 & $\ddot{\lambda}$ & $\stackrel{n}{\vartheta}$ \\
\hline 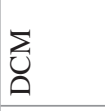 & 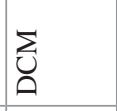 & 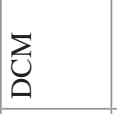 & 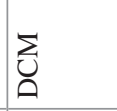 & 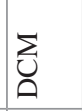 & 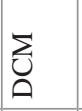 & 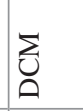 & 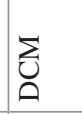 & $\begin{array}{l}\dot{n} \\
\ddot{Z}\end{array}$ & $\dot{P}$ & 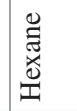 \\
\hline 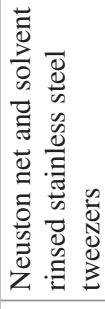 & 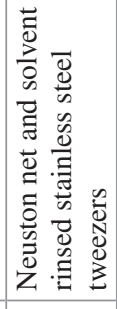 & 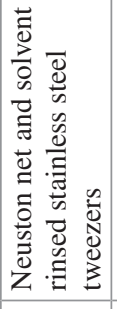 & 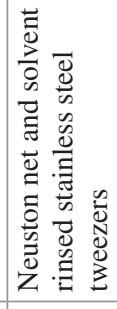 & 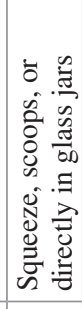 & 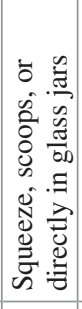 & 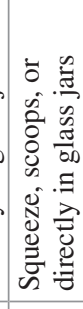 & 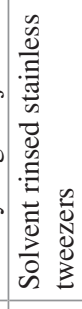 & 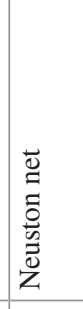 & 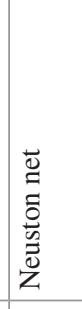 & 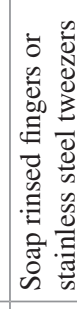 \\
\hline 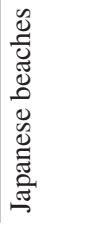 & 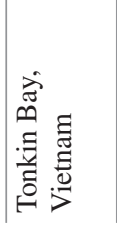 & 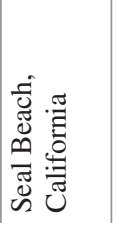 & 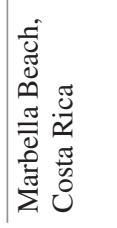 & $\begin{array}{l}:= \\
\text { 寻 } \\
\text { 完 }\end{array}$ & 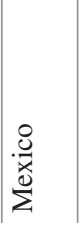 & 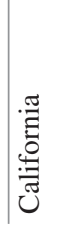 & 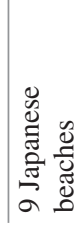 & 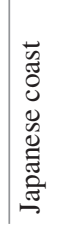 & 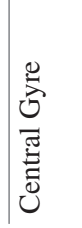 & 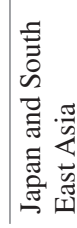 \\
\hline
\end{tabular}




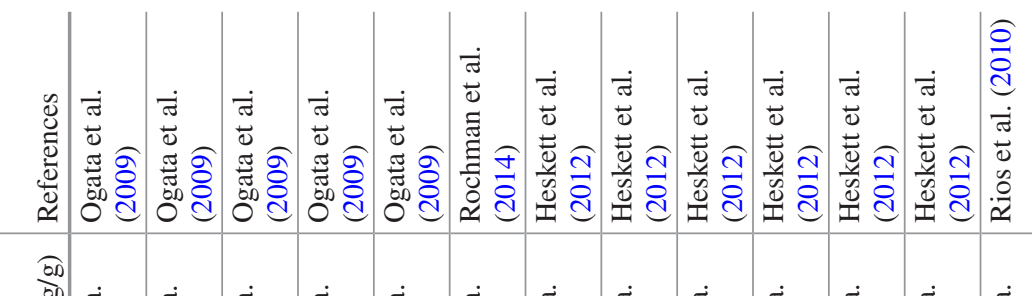

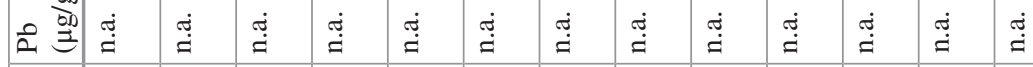

\begin{tabular}{|c|c|c|c|c|c|c|c|c|c|c|c|}
\hline$\tilde{U}^{\frac{60}{60}} \stackrel{0}{\Xi}$ & $\stackrel{\overbrace{}}{=}$ & 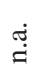 & 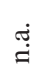 & 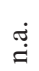 & 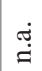 & 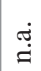 & $\stackrel{\leftrightarrow}{\operatorname{d}}$ & 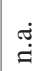 & $\stackrel{\leftrightarrow}{\operatorname{d}}$ & 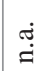 & 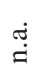 \\
\hline
\end{tabular}

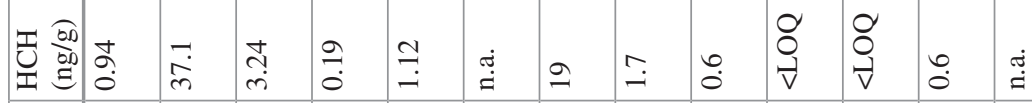

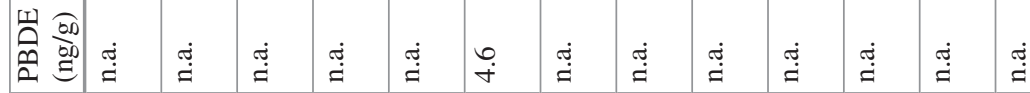

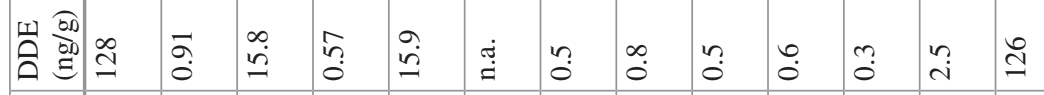

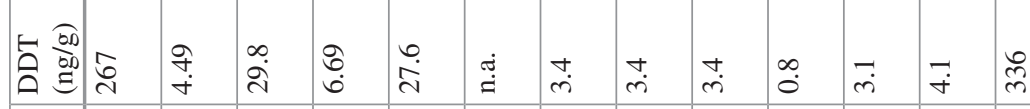

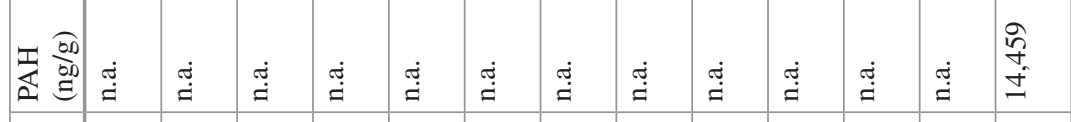

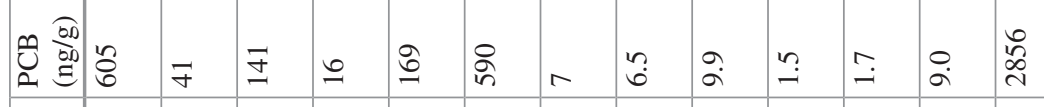

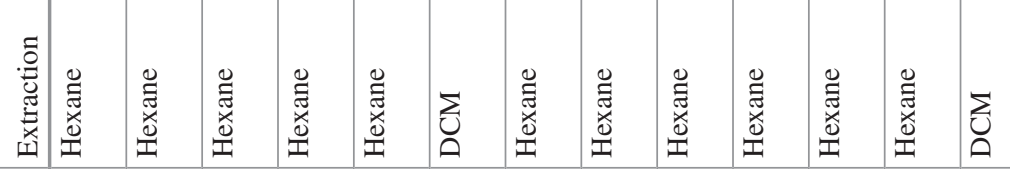

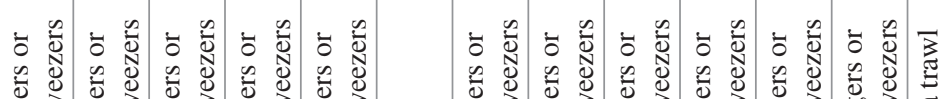

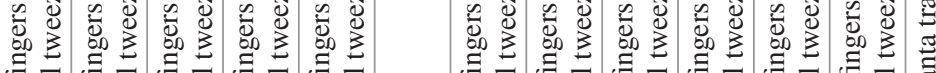

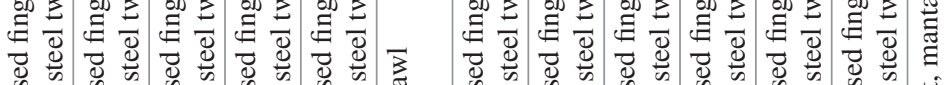

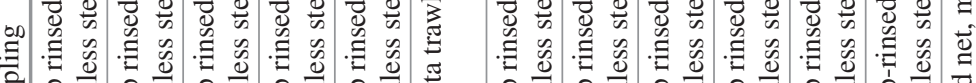

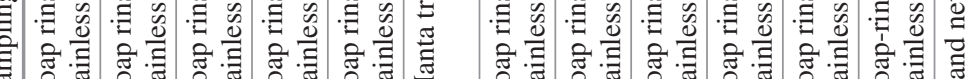

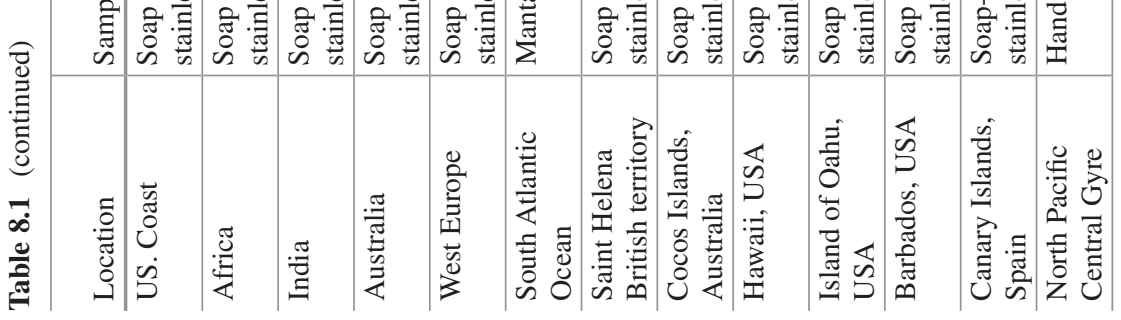




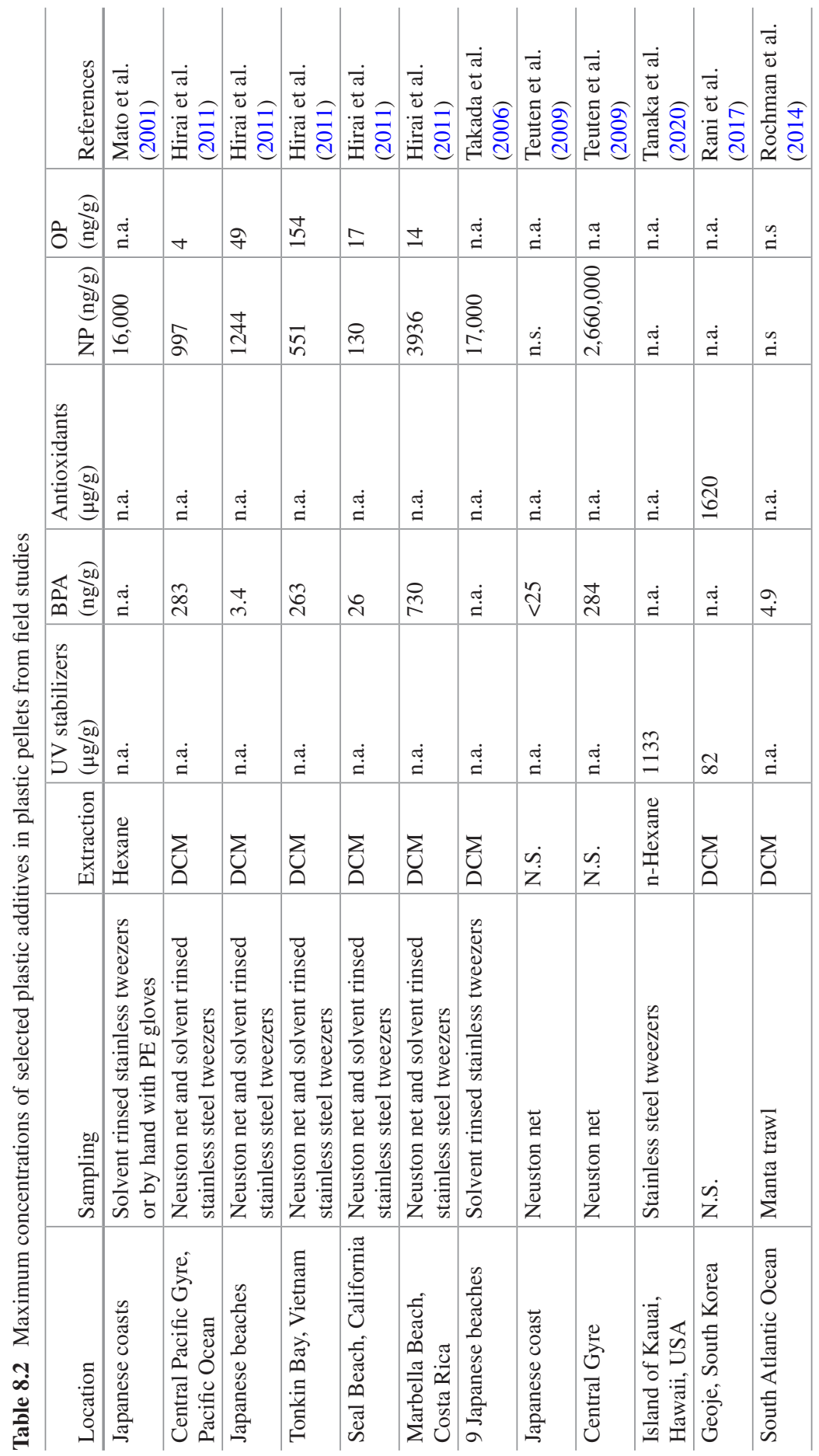


steric, non-covalent, or covalent bonds (i.e. $\pi-\pi$ interactions) (Brennecke et al. 2016; Hüffer and Hofmann 2016; Velzeboer et al. 2014; Wang et al. 2019).

Sorption is also largely influenced by the surface area to volume ratio of a plastic particle, which increases as the size decreases (Brennecke et al. 2016; Li et al. 2019; Ma et al. 2016; Teuten et al. 2009; Zhan et al. 2016; Zhang et al. 2018). When exposed to weathering, the plastic surface can be subjected to embrittlement and fragmentation, steps that increase the surface/volume and provide more space, a larger contact area, and new sorption sites for external molecules (Napper et al. 2015; Wang et al. 2018b). UV rays-induced weathering, or photo-oxidation, can also lead to chemical alterations and loss of hydrophobicity through the creation of new oxygen-rich functional groups (i.e. carbonyl moieties). Salinity and $\mathrm{pH}$ can also play a role in sorption mechanisms. When $\mathrm{pH}$ is above the point of zero charge (PZC) of the plastic polymer, it assumes a negative charge that could result in electrostatic repulsion between its surface and other anionic chemicals (Holmes et al. 2014; Li et al. 2019; Wang et al. 2015). Salinity, on the other hand, can either increase the partitioning of nonpolar compounds (salting out) or decrease that of polar molecules due to competition in the adsorption sites (Karapanagioti and Klontza 2008; Llorca et al. 2018; Wang et al. 2015; Zhan et al. 2016; Zuo et al. 2019). This can result in a difference in sorption capacities between freshwater and seawater environments. Exposure time, chain length, and temperature have also been observed as influential factors in hydrophobic partitioning (Engler 2012; Llorca et al. 2018; Mato et al. 2001; Takada et al. 2006; Zhan et al. 2016; Zhang et al. 2018).

Finally, it must be noted that new kinds of biodegradable plastic polymers are being designed and are expected to be more easily and fully degraded over a short time, thus reducing their potential harm. Despite this assumption, Zuo et al. (2019) recently indicated that those highly rubbery MP could become even stronger vectors of organic chemicals. Evaluation of toxicity of the alternative materials and experimental studies are needed to clarify the possible harm.

\subsubsection{Polycyclic Aromatic Hydrocarbons (PAHs)}

The presence of polycyclic aromatic hydrocarbons (PAHs) in the environment can be the result of three different processes: the incomplete combustion of organic material (pyrolytic origin), spillage discharge of crude oil (petrogenic origin), or the post-depositional transformation of biogenic precursors (diagenetic origin). The contribution of petrogenic over pyrogenic sources (and vice versa) can be manifested through the calculation of the ratio between lighter (2-3 rings) and heavier congeners (4-6 rings), with higher values of this parameter indicating a major contribution of fossil sources (low molecular weight congeners). High molecular weight PAHs are generally the ones detected at higher concentrations on plastic pellets in 
the environment, implying combustion processes to be the main source of contamination (Gauquie et al. 2015; Rios et al. 2007). In a recent study, low molecular weight PAHs were mostly found on clearer materials, while high molecular weight PAHs were mostly detected on darker materials (Fisner et al. 2017). The colour of microplastics, along with their size and smell, is an important factor since some organisms may selectively feed on those pellets which resemble their prey (Chagnon et al. 2018; Hipfner et al. 2018; Ory et al. 2017; Savoca et al. 2016).

\subsubsection{Polychlorinated Biphenyls (PCBs)}

Polychlorinated biphenyls (PCBs) are a group of 209 lipophilic chemicals of a completely anthropogenic origin, which have been widely used from the 1930s to 1970s until they were banned because of their harmful nature.

The concentration of these pollutants in plastic pellets nowadays is mostly related to the presence of legacy PCBs in those industrialized countries that formerly used high amounts of them, which are still present in the environment due to their persistent nature (Ogata et al. 2009). When lower chlorinated congeners are detected inside an organism, their presence can be generally linked to the ingestion of contaminated MPs, since they would be more easily depleted along the trophic chain (Teuten et al. 2009). For this, only those highly substituted congeners would be more prone to be transferred and biomagnify in the trophic chain, and their exposure would then be mainly caused by prey ingestion (Yamashita et al. 2011). However, due to the high $\mathrm{K}_{\text {ow }}$ of highly chlorinated PCBs, they are more efficiently bound to the plastic and then less likely released from polymers (Colabuono et al. 2010). Their concentration is typically expressed as ICES-7 ( $\Sigma$ PCBs 28, 52, 101, 118, 138, 153, 180), which corresponds to the sum of seven indicator non-dioxin-like (NDL) congeners presenting the highest concentrations in technical mixtures and the environment (Webster et al. 2013). They are generally calculated as the sum of different congeners. The ones typically showing the highest concentrations are CB 118, 138, 153, 170, and 180 (Antunes et al. 2013; Colabuono et al. 2010; Gauquie et al. 2015; Mato et al. 2001; Yamashita et al. 2011). Congeners 138,153 , and 180 are the ones mostly detected in human serum and tissues (JECFA 2016).

Moreover, among PCBs, 12 congeners have a coplanar conformation (dioxinlike PCBs) that enables them to interact with xenobiotic receptors in the cell (i.e. aryl hydrocarbon receptor, $\mathrm{AhR}$ ) and makes them able to interfere with the endocrine system, causing reproductive disorders among others (JECFA 2016; Pocar et al. 2005). 


\subsubsection{Dichlorodiphenyltrichloroethane (DDT)}

Dichlorodiphenyltrichloroethane (DDT) is an organochlorine compound used as an insecticide. Total DDT concentration (tDDT) is usually expressed as the sum of DDT and its metabolites DDD and DDE (Antunes et al. 2013; Hirai et al. 2011; Ogata et al. 2009; Rios et al. 2007). When DDE/DDT ratio is very small, it indicates recent contamination. High levels of DDT in the environment and on plastics can be ascribed to their high production levels, especially by the USA, their intensive use as pesticides in agriculture, and as insecticides (JECFA 1961). While DDT production has been banned in some countries such as the USA since 1972, DDT and its derivatives are still in use as insecticides in some countries to prevent the spread of malaria.

\subsubsection{Polybrominated Diphenyl Ethers (PBDEs)}

Polybrominated diphenyl ethers (PBDEs) are a group of 209 anthropogenic chemicals produced and added to materials in order to improve their resistance to fire. They make up one of the major classes of brominated flame retardants (BFR). They are part of the group of lipophilic, persistent organic contaminants, can be accumulated through the food chain, and converted from one congener to another through metabolization. Their concentration in commercial products and, thus, their occurrence in the environment are not as high as those of PCBs. Industrial products are mostly made up of few congeners, so environmental data are available only for penta- hepta-, octa- and deca-BDEs, among which BDE-47 is the most abundant together with BDE-99, BDE-100, and BDE-209 (Darnerud et al. 2001). Their exposure is generally associated with hypothyroidism, since they can bind to thyroid hormone transporters, act as agonists/antagonists, or displace the bound hormones (Darnerud et al. 2001).

The congeners most commonly analysed to check contamination in feed and food are BDE-28, BDE-47, BDE-99, BDE-100, BDE-153, BDE-154, BDE-183, and BDE-209 (EFSA 2011). The $\log \mathrm{K}_{\mathrm{ow}}$ of these highly hydrophobic congeners ranges from 5.94 to more than 8 (Braekevelt et al. 2003). This class of POPs has among the greatest potential to cause harm to biological systems even at low concentrations (Abdelouahab et al. 2009; Carlson 1980; Fair et al. 2012).

\subsubsection{Hexachlorocyclohexanes (HCHs)}

Hexachlorocyclohexanes (HCHs) are long-range transported organochlorine pesticides that were mostly used either in agriculture or as insecticides. Several isomers can be present in the commercial mixtures, and when performing environmental 
analyses, their concentration is expressed as $\Sigma \mathrm{HCH}(\alpha-\mathrm{HCH}, \beta-\mathrm{HCH}, \gamma-\mathrm{HCH}$, and $\delta-\mathrm{HCH}) \cdot \gamma-\mathrm{HCH}$, the major component of pesticides, was found as the most abundant isomer in plastic samples from Mozambique and South Africa (Ogata et al. 2009). $\log \mathrm{K}_{\mathrm{ow}}(\gamma-\mathrm{HCH}=3.8)$ for HCHs is lower than that for PCBs and DDTs, and they are thus supposed to partition the plastic pellets less than the other more hydrophobic chemicals (Mizukawa et al. 2013).

\subsection{Desorption of Environmental Pollutants from Microplastics}

New evidence implies a possible transfer of persistent, bioaccumulative, and toxic (PBT) pollutants into organisms from contaminated plastics (Avio et al. 2015; Browne et al. 2013; Chua et al. 2014; Engler 2012; Ryan et al. 1988; Tanaka et al. 2013; Wardrop et al. 2016; Yamashita et al. 2011). This would lead to an increased exposure to xenobiotic molecules once the plastic item is ingested.

Considering that the bond between a co-contaminant and the plastic substrate can be reversible, sorbed POPs will tend to desorb from the polymer into the water until equilibrium is finally attained (Andrady 2011). The desorption behaviour can be enhanced by the presence of some chemical surfactants, which are molecules able to increase the solubility of hydrophobic substances. These molecules possess an amphipathic nature, containing both hydrophilic and hydrophobic moieties, enabling them to interact with the two phases. Their mechanism of action consists of the lowering of aqueous phase polarity and the formation of micelles to include and contain the nonpolar chemicals. Among them, humic acids and linear alkyl benzene sulphonate, which can be found in the environment, have been found to significantly affect PCDD/DFs and PCBs leaching in some shredder residues and municipal solid waste (Sakai et al. 2000). In the gut, some digestive detergents are present and, through their surfactant properties, could induce the release of toxic substances from the ingested MPs, in a process that is negatively correlated with lipophilicity (Ahrens et al. 2001; Heinrich and Braunbeck 2019). This could suggest a higher degree of bioavailability.

\subsubsection{Leaching of Additives from Microplastics}

Many of the plastic additives (plasticizers, PBDEs flame retardants, antioxidants, and stabilizers) are not chemically bound to the polymer and can thus more easily migrate from the material. Only some reactive organic additives, such as some flame retardants, are polymerized with the plastic molecules becoming part of the polymer chain. All these chemicals are intentionally added during plastic manufacture in order to give plastics some specific features and improve their functional 
characteristics (e.g. UV and thermal resistance, flexibility). These compound are mixed within the bulk matrix, and their leaching behaviour can be influenced and enhanced by external factors, such as changes in temperature or $\mathrm{pH}$, plastic ageing, and the presence of surfactants (Suhrhoff and Scholz-Böttcher 2016; US EPA 1992; Wei et al. 2019).

\subsection{Microplastics and Nanoplastics Occurrence in Foods}

Microplastic pollution has become a potential food safety threat that is especially relevant for fishery products as well as other seafood products including table salt. Although microplastics have been reported in products such as honey and sugar (Liebezeit and Liebezeit 2013) or beer (Liebezeit and Liebezeit 2014), aquatic products and water seem to be the best-studied source of dietary intake of microplastics.

\subsubsection{Microplastics and Nanoplastics Occurrence in Fisheries and Aquaculture Products}

Ingestion of microplastics by aquatic organisms have been reported in numerous studies; indeed, microplastics have been found in 12 out of the 25 most important species and genera that contribute to global marine fisheries (FAO 2017).

Small concentrations of microplastics of around one to two particles per fish have been observed in many important commercial species such as sardine, mackerel, anchovy, herring, and sprat from the Pacific, Atlantic, and Indian oceans, as well as the Mediterranean Sea (GESAMP 2016; Lusher et al. 2016). Other aquatic species of local and regional relevance from marine and freshwater environments have been found to contain microplastic particles too (FAO 2017).

Most microplastics have been observed in the gastrointestinal tract of fish, where most particles seem to concentrate after ingestion. However, several studies in marine organisms have shown that smaller microplastics and nanoplastics could be translocated in other organs such as the liver, although the translocation pathways are not well understood yet (Collard et al. 2017).

Bivalve molluscs have also been found to contain microplastic particles. One of the best-studied are mussels, where their occurrence has been reported in Europe, North America, Brazil, and China. The lowest level of microplastic concentration in mussels (less than 0.5 particle/g) was observed in Europe and the highest concentration of microplastics in mussels was reported in China, amounting to 4 particles/g (EFSA 2016).

Microplastics have also been observed in crustaceans, such as shrimps and in $83 \%$ of Norway lobsters in coastal waters of the North Sea and the Irish Sea, with 
average concentrations ranging from 0.03 to 1.92 particles/g in shrimp, mostly found in the digestive tract (Devriese et al. 2015; Murray and Cowie 2011).

An emerging threat to the consumption of fisheries and aquaculture products derives from the ability of microplastics to sorb environmental contaminants as persistent organic pollutants (POPs), metals, and pathogens, where its concentration can be several folds higher than in the water column. Humans can be exposed to these contaminants through the consumption of fisheries products especially bivalves and crustaceans, where the gastrointestinal tract is not removed. Another route of exposure might be the consumption of farmed species fed with contaminated fish or fishmeal (GESAMP 2016). Information on microplastics presence in different marine organisms (including commercial seafood species), sampling method/instrument, polymer type, and particle size are summarized in Table 8.3.

\subsubsection{Microplastics and Nanoplastics Occurrence in Salt}

Microplastics may contaminate table salt, as other sea products, and their occurrence has been reported in different countries such as Italy, Croatia, and Spain. The average microplastic content in Italy fluctuated from 1.57 (high-quality table salt) to 8.23 (low-quality table salt) particles/g, with a size range from $4 \mu \mathrm{m}$ to $2100 \mu \mathrm{m}$. The results in Croatia fluctuated from and 27.13 (high-quality table salt) to 31.68 (low-quality table salt) particles/g with an average size range from 15 to $4628 \mu \mathrm{m}$ (Renzi and Blašković 2018).

In Spain, microplastics were found in commercial table salt. The content went from 50 to 280 particles $/ \mathrm{kg}$, being PET the most frequently reported polymer, followed by PP and PE (Iñiguez et al. 2017).

\subsubsection{Microplastics and Nanoplastics Occurrence in Water}

The presence of microplastics has been reported in raw and treated drinking water. Depending on the water treatment, microplastic particles are found in different concentrations in water samples. Their average abundance was described from $1473 \pm 34$ to $3605 \pm 497$ particles/L in raw water and from $338 \pm 76$ to $628 \pm 28$ particles/L in treated water, depending on the treatment (Pivokonsky et al. 2018). A relevant finding is that some microplastic particles were reported to be down to the size of $1 \mu \mathrm{m}$ and around 12 different microplastics compounds were identified, being PET, PP, and PE the most prominent polymers. 


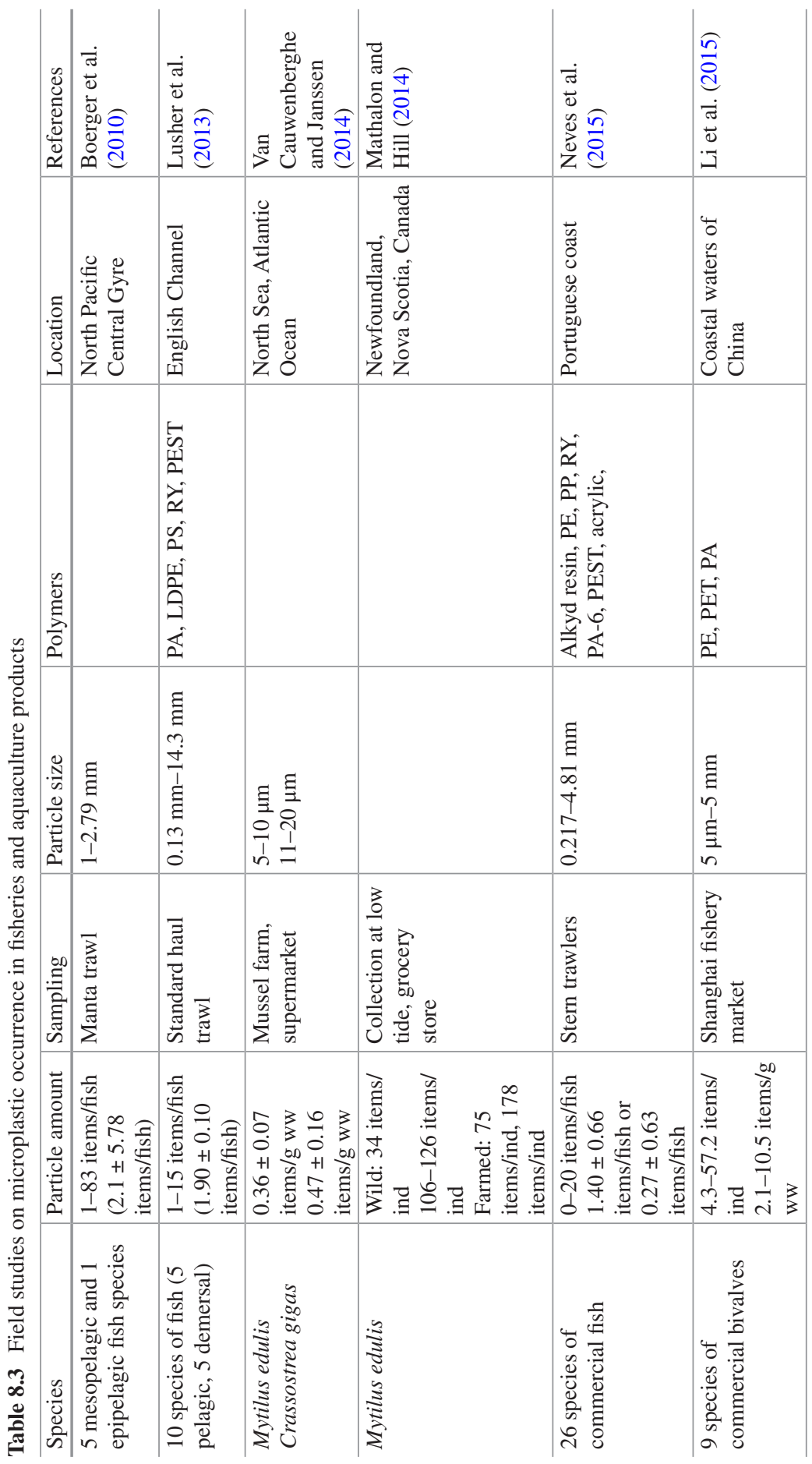




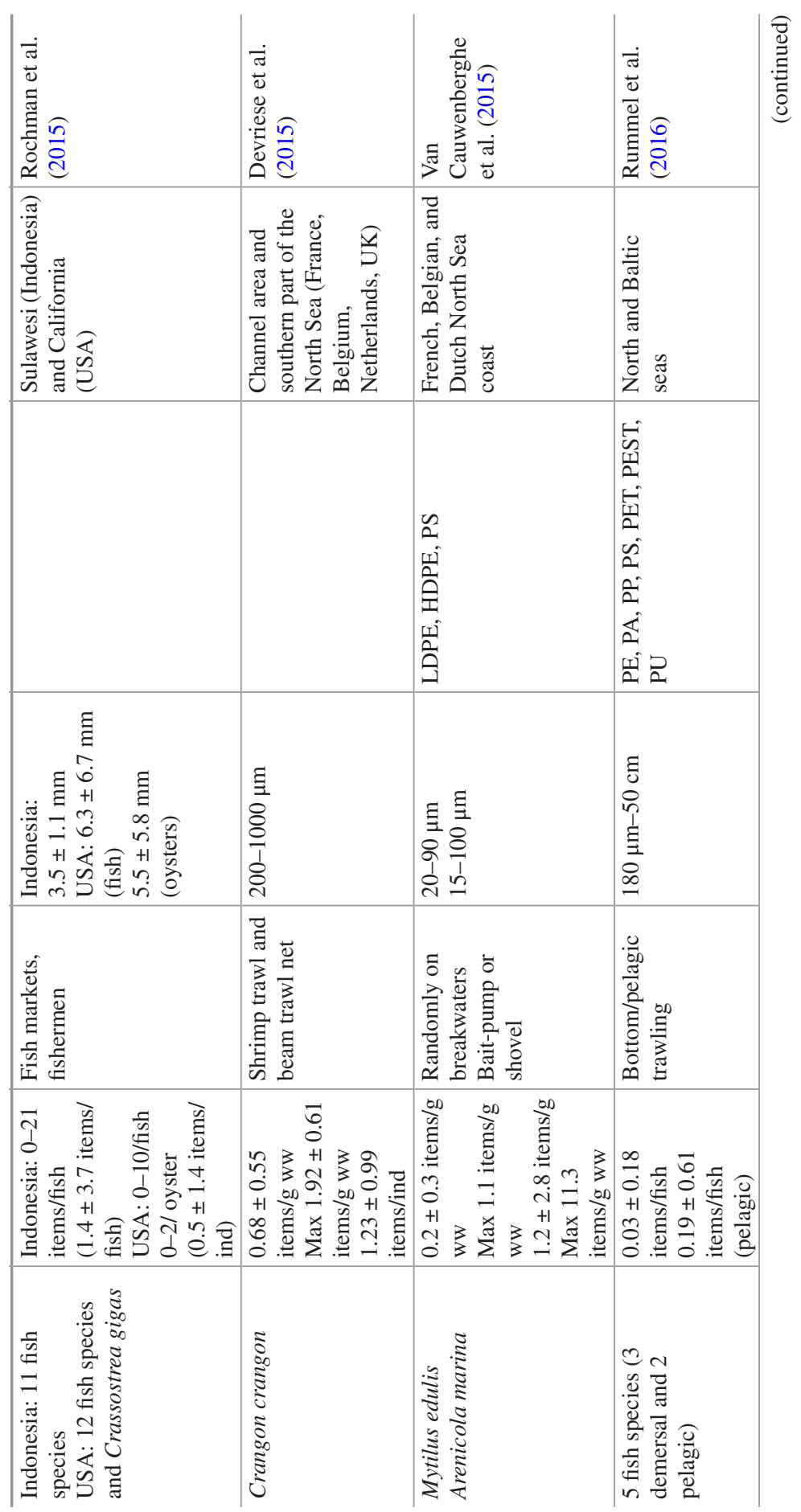




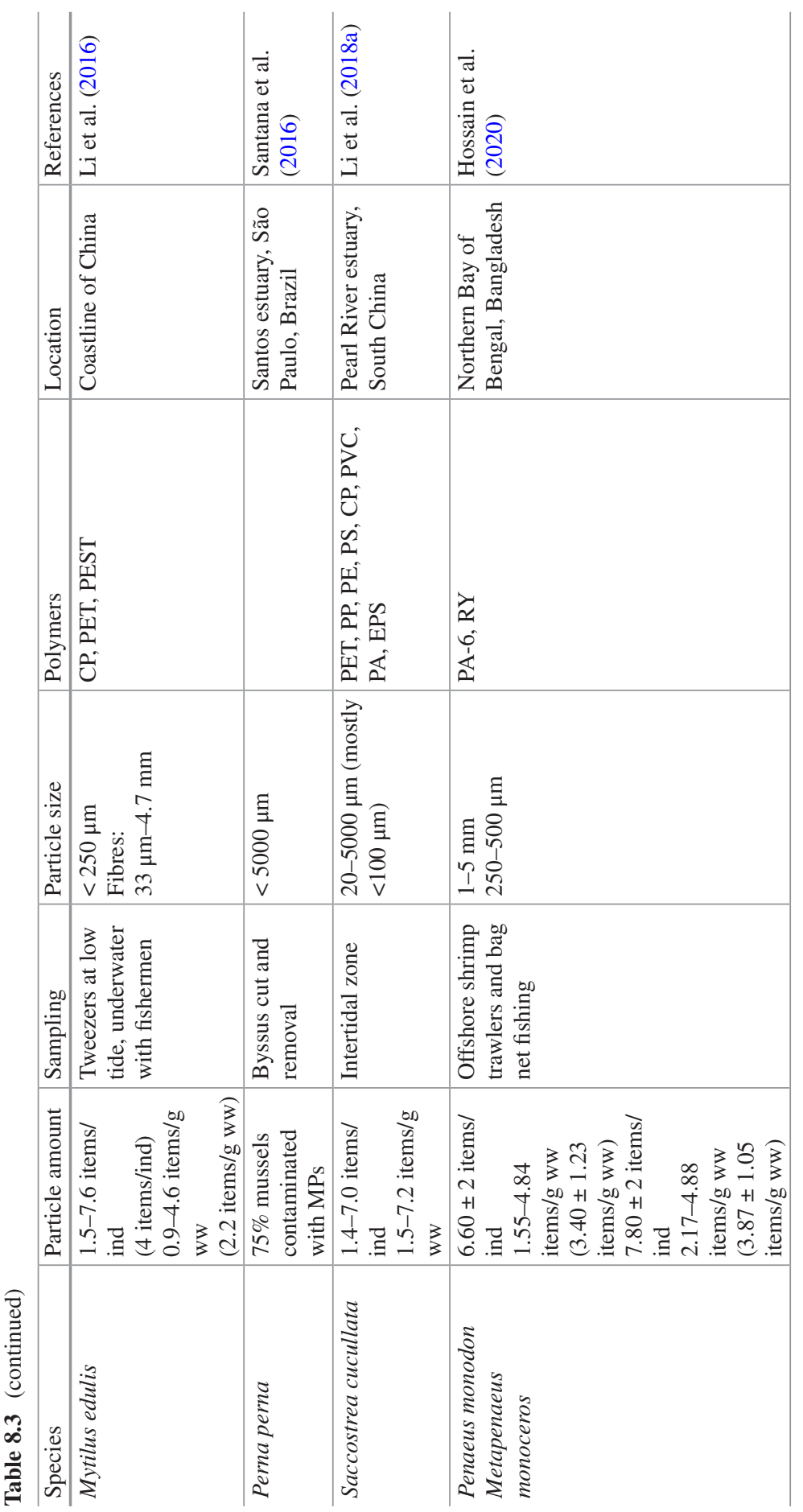




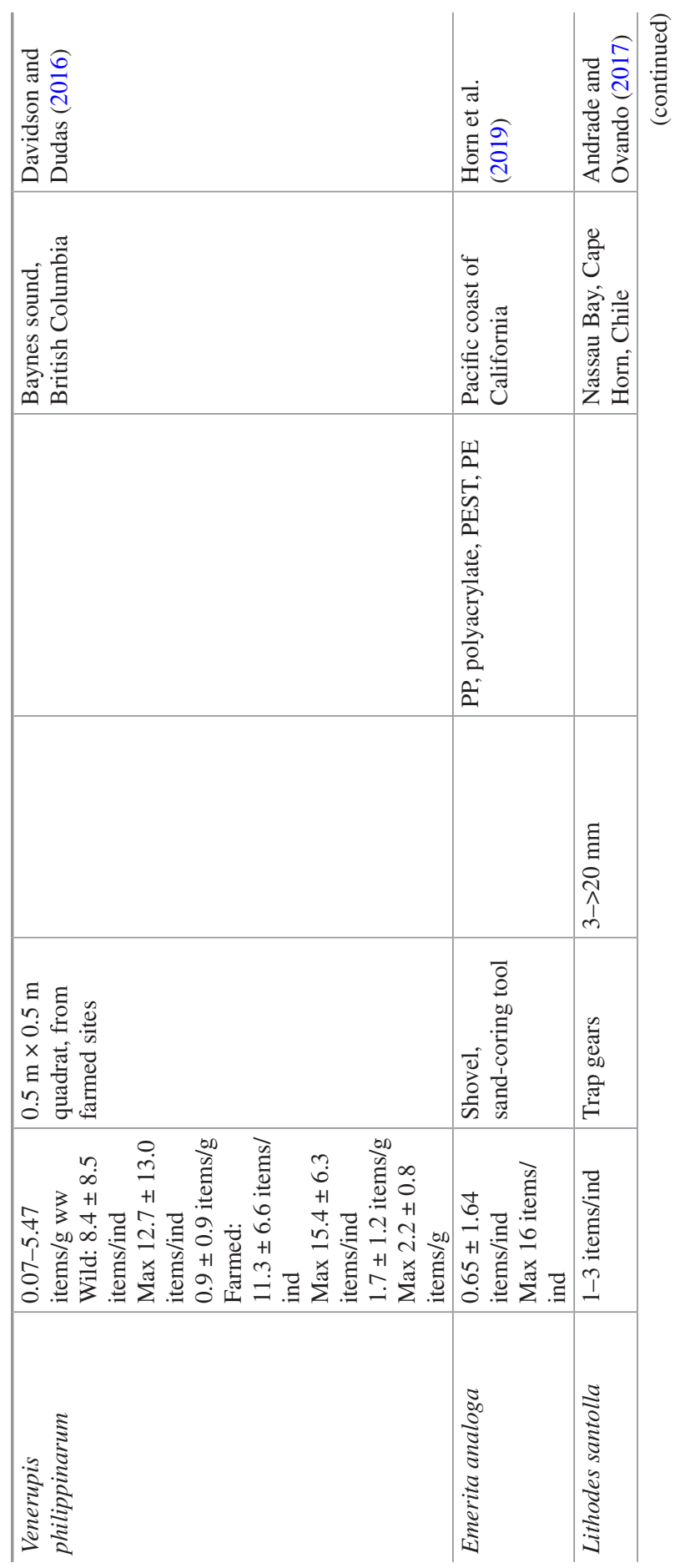




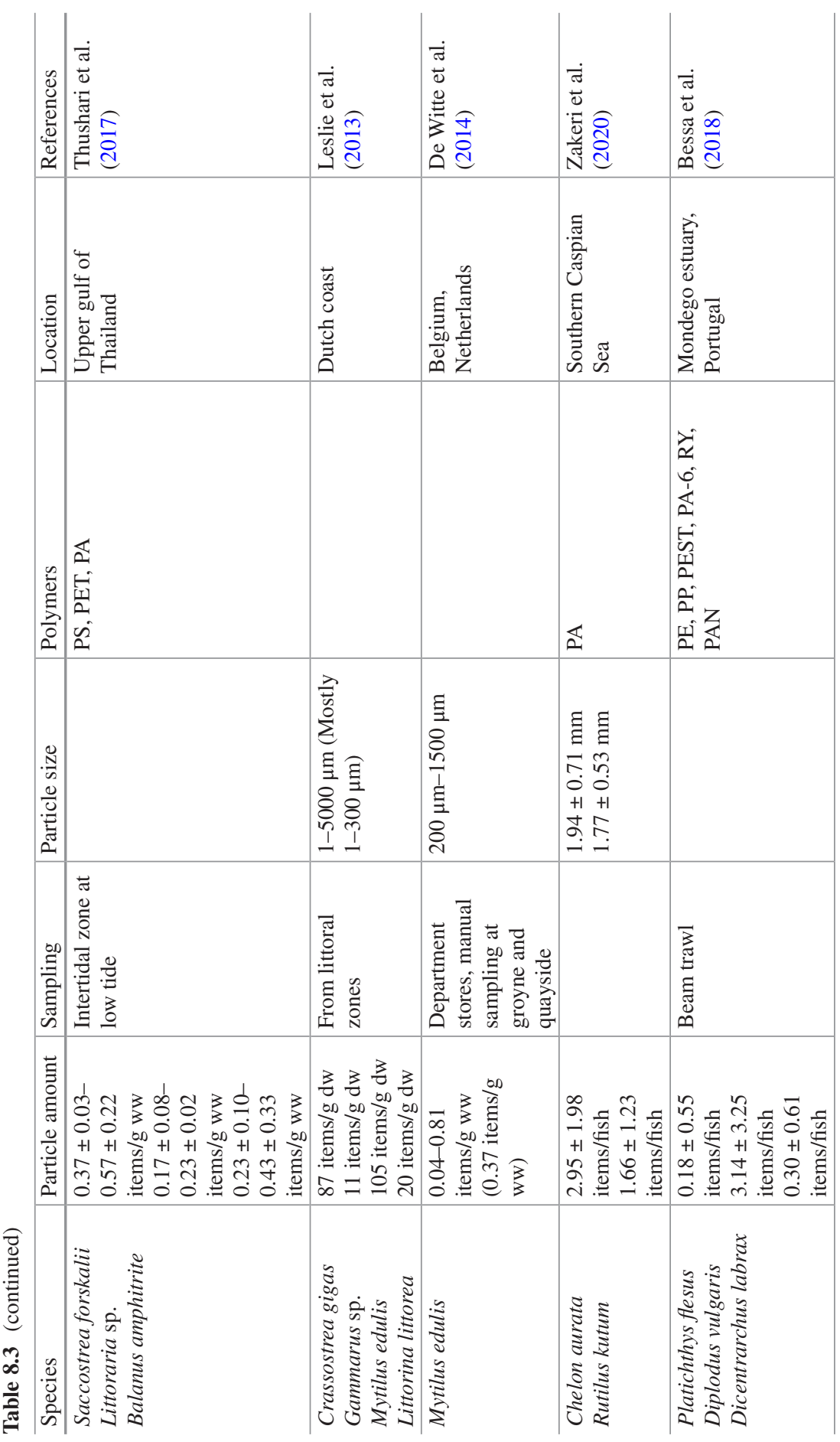


8 Dietary Exposure to Additives and Sorbed Contaminants from Ingested...

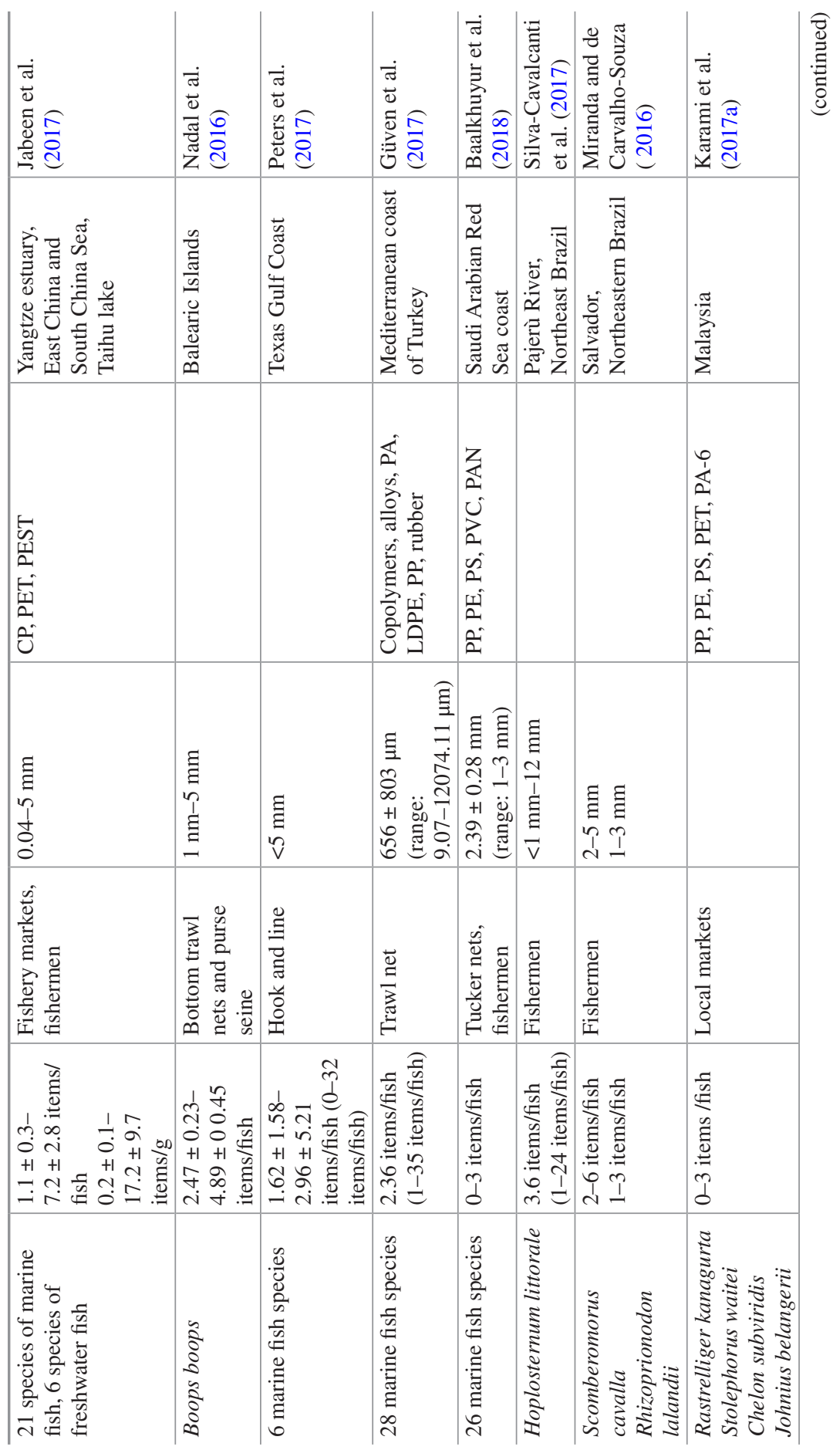




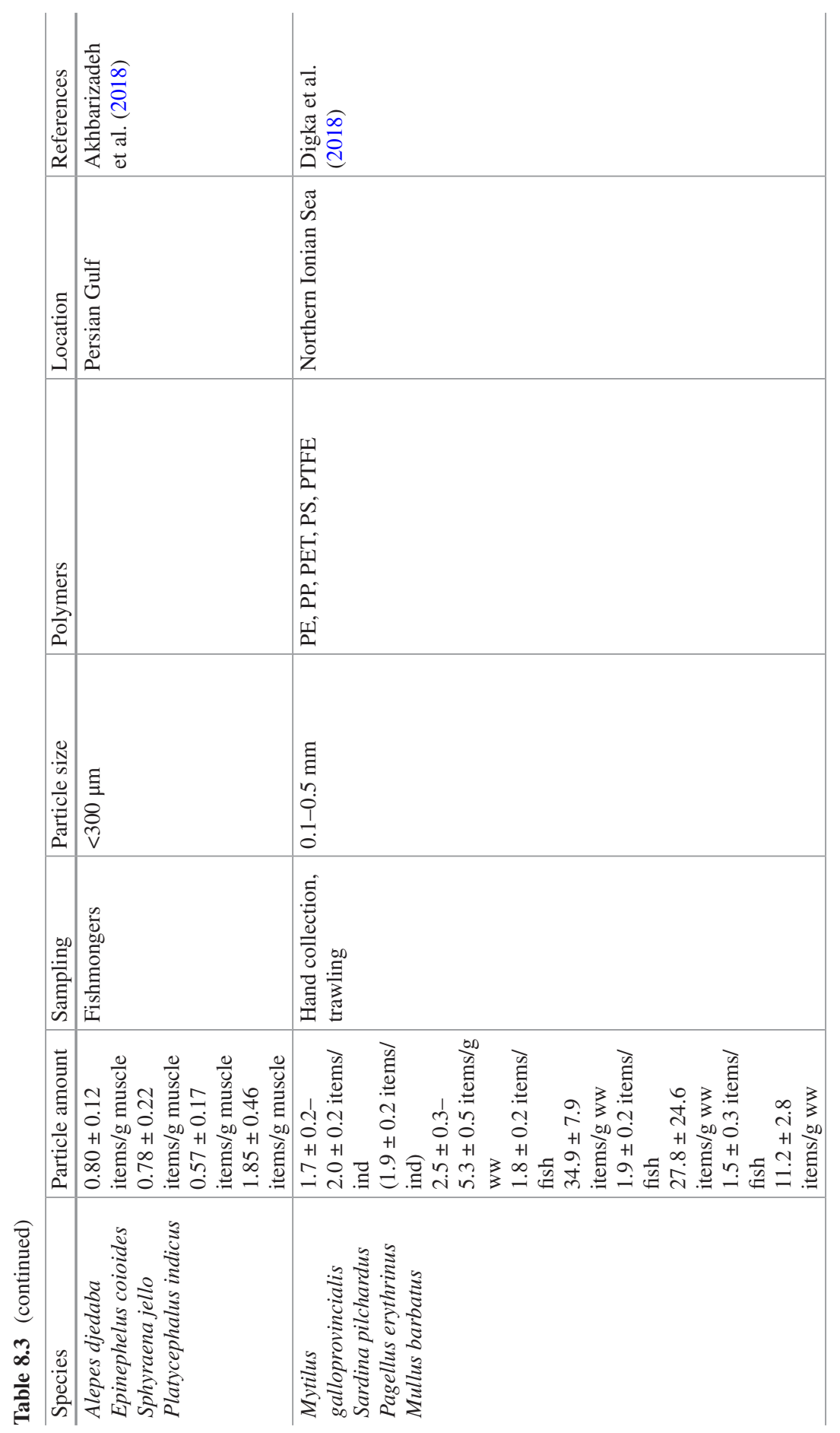




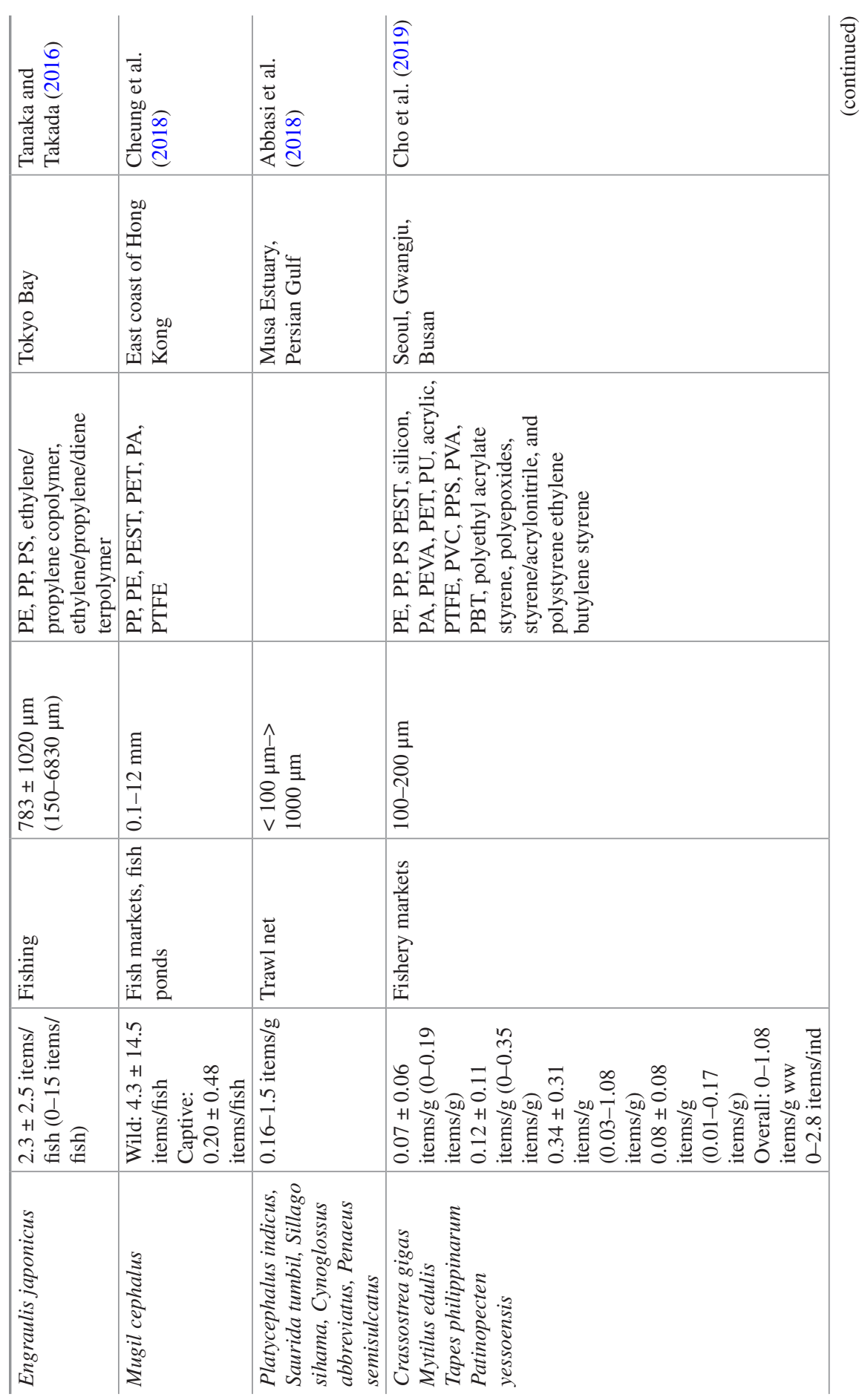




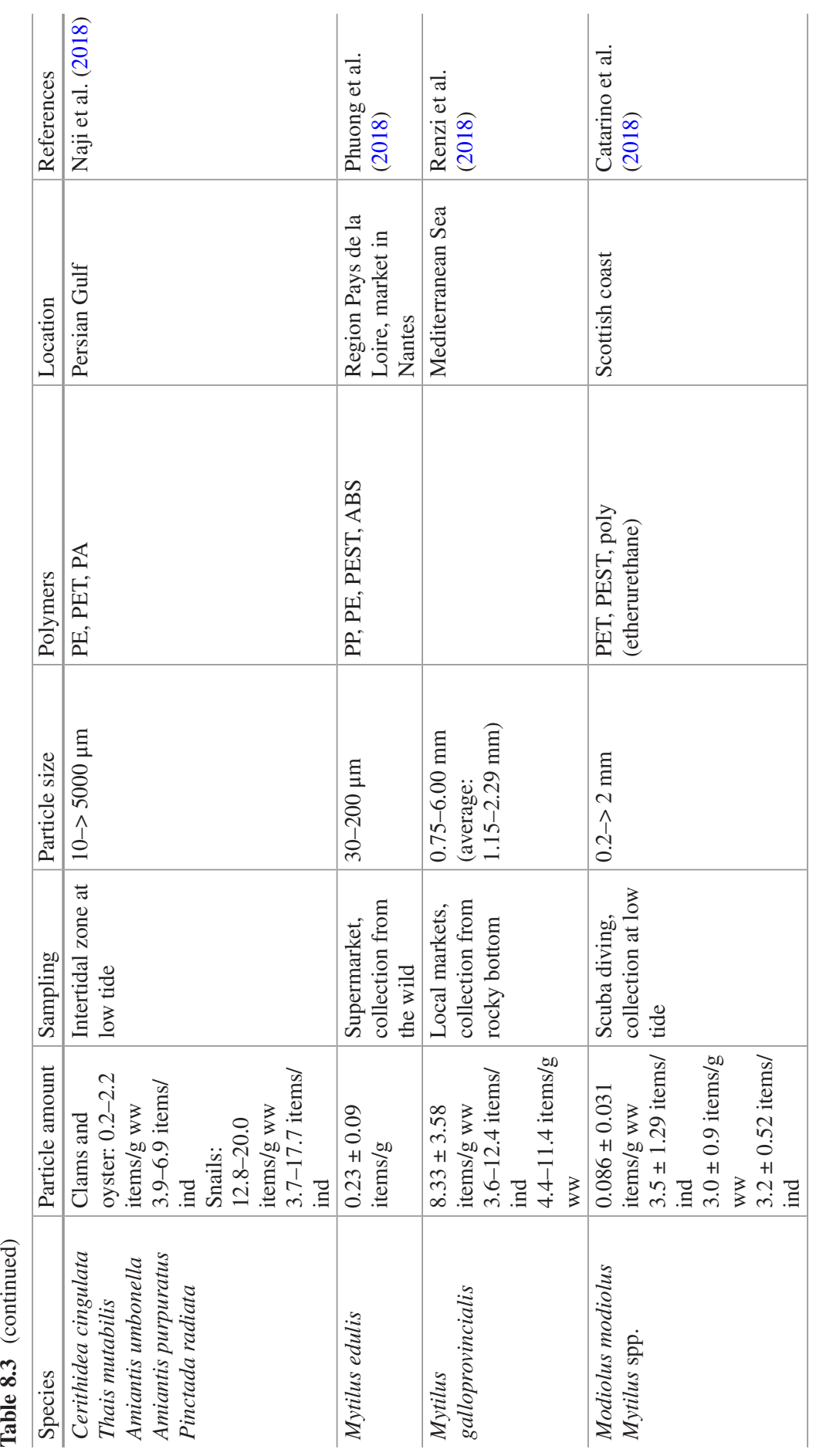




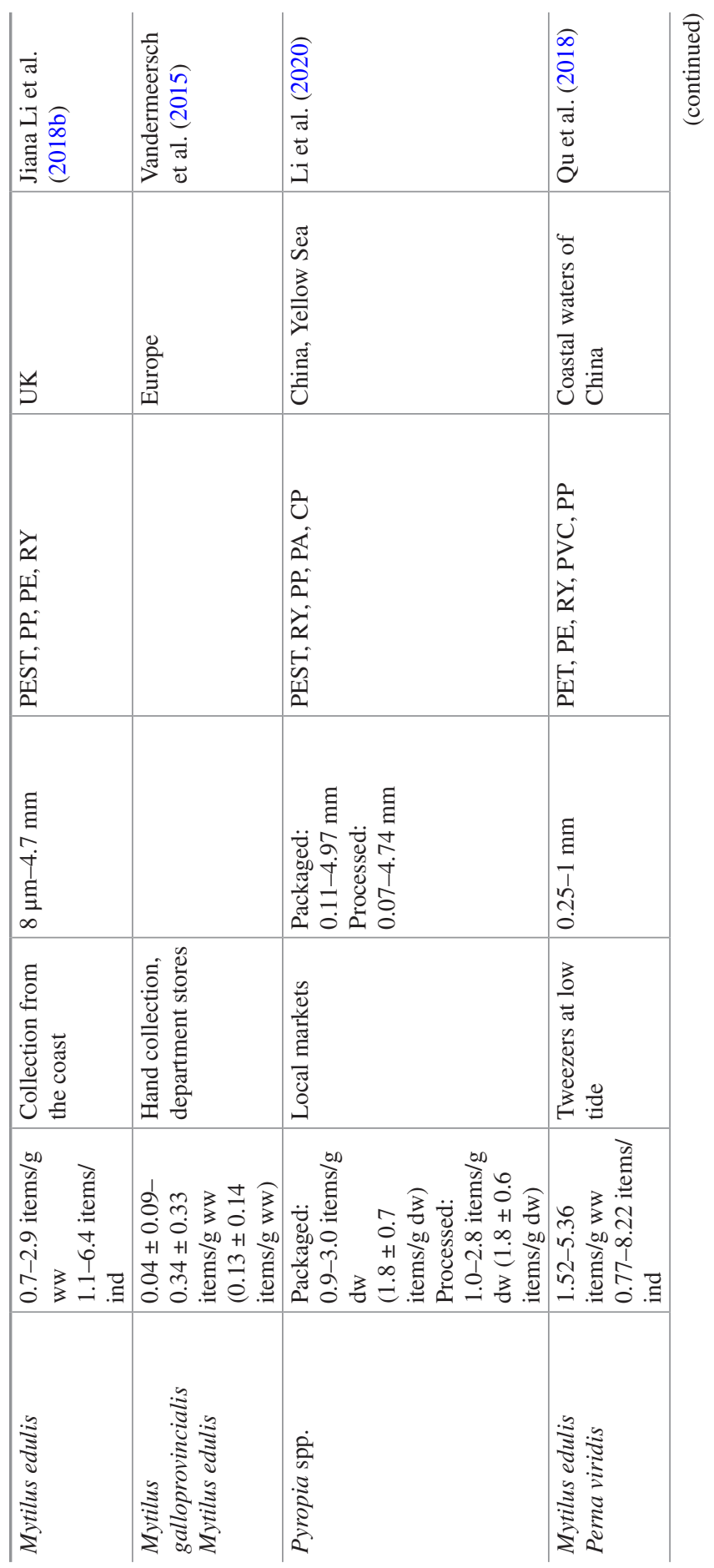




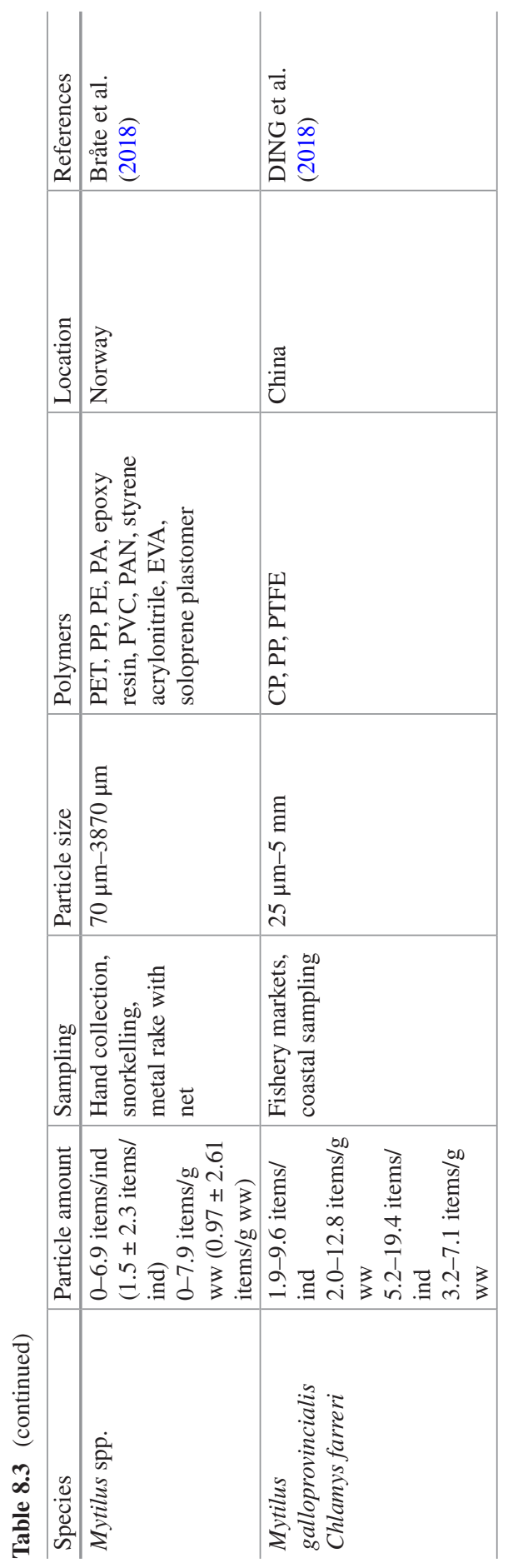




\subsection{Risk Profiling of Microplastics in Fisheries and Aquaculture Products}

\subsubsection{Microplastics Dietary Intake}

The dietary intake of microplastics in foods depends on consumption habits, especially when dealing with fisheries and aquaculture products that mainly accumulate microplastics in the gastrointestinal tract, which minimizes the direct exposure to these particles when aquatic products are degutted. Previous studies and reviews have provided some estimates of human intake of microplastic particles through the consumption of different food commodities, and their results are illustrated in Table 8.4.

Exposure can be higher through consumption of small aquatic species such as crustaceans, echinoderms, bivalves, and small-sized fish that are commonly eaten whole. Microplastics have been also found in the muscle of canned, dried, and fresh commercial fish species, suggesting that evisceration may not be a completely efficient process, but the number of particles found in muscle is relatively low compared to the number of particles in the gastrointestinal tract (Abbasi et al. 2018; Akhbarizadeh et al. 2018; Karami et al. 2018, 2017a). In crustaceans such as shrimps, peeling practices that remove most of the digestive tract, the head, and the gills will reduce the exposure to plastics, as these parts are estimated to contain 90 percent of the microplastic particles (Devriese et al. 2015).

In Europe, human exposure to microplastics resulting from the consumption of bivalves may account for 1800 to 11,000 particles/year (Van Cauwenberghe and Janssen 2014). Mussels are among the most consumed bivalve molluscs, and the occurrence of microplastics in these products has been reported in several studies (EFSA 2016).

\subsubsection{Microplastics Uptake and Toxicity}

The physical characteristics of microplastic particles (size, shape), as well as the chemical characteristics, in addition to leaching of additives and pollutants or transport of pathogens, are the main factors for estimating the impact of these particles on food safety, but literature at this respect is indeed limited, and evidence of a possible transfer through the diet are lacking, as are the possible consequences.

Some studies have shown that small plastic particles are able to cross human placenta (Ragusa et al. 2021; Wick et al. 2010), which suggests a possible systemic increase in exposure as their size decreases (De Jong et al. 2008). The most frequent route of uptake would be absorption from the gut epithelium into the lymphatic system (Hussain et al. 2001). Absorption from the intestine is known to be very limited, and it should occur only for those microparticles $<150 \mu \mathrm{m}$ (EFSA 2016; FAO 2017). According to their size, particles are supposed to face different densities 
Table 8.4 Previous estimates of exposure to microplastics through the consumption of seafood, water, and salt

\begin{tabular}{|c|c|c|c|c|}
\hline Food & $\begin{array}{l}\text { Reference } \\
\text { intake }\end{array}$ & $\begin{array}{l}\text { Derived MP } \\
\text { intake }\end{array}$ & Country & References \\
\hline Molluscs & $\begin{array}{l}72.1 \mathrm{~g} / \text { day (top } \\
\text { consumers) } \\
11.8 \text { g/day } \\
\text { (minor } \\
\text { consumers) }\end{array}$ & $\begin{array}{l}11,000 \mathrm{MP} / \text { year } \\
\text { (top consumers) } \\
1800 \mathrm{MP} / \text { year } \\
\text { (minor } \\
\text { consumers) }\end{array}$ & Europe & $\begin{array}{l}\text { Van Cauwenberghe and Janssen } \\
\text { (2014) }\end{array}$ \\
\hline Fish muscle & $\begin{array}{l}300 \mathrm{~g} / \text { week } \\
\text { (adults) } \\
50 \mathrm{~g} / \mathrm{week} \\
\text { (children) }\end{array}$ & $\begin{array}{l}\text { 169-555 MP/ } \\
\text { week (adults) } \\
\text { 28-92 MP/week } \\
\text { (children) }\end{array}$ & Iran & Akhbarizadeh et al. (2018) \\
\hline Bivalves & $3.01 \mathrm{~g} /$ day & $212 \mathrm{MP} /$ year & $\begin{array}{l}\text { South } \\
\text { Korea }\end{array}$ & Cho et al. (2019) \\
\hline Shellfish & $4.03 \mathrm{~g} /$ day & $283 \mathrm{MP} /$ year & $\begin{array}{l}\text { South } \\
\text { Korea }\end{array}$ & Cho et al. (2019) \\
\hline Mussels & $82 \mathrm{~g} /$ year & $123 \mathrm{MP} /$ year & UK & Catarino et al. (2018) \\
\hline Mussels & $3.08 \mathrm{~kg} /$ year & $4620 \mathrm{MP} /$ year & $\begin{array}{l}\text { Spain/ } \\
\text { France/ } \\
\text { Belgium }\end{array}$ & Catarino et al. (2018) \\
\hline Mussels & $225 \mathrm{~g}$ & $\begin{array}{l}7 \mu \mathrm{g} \\
0.1 \mu \mathrm{g} / \mathrm{kg} \text { bw/ } \\
\text { day }\end{array}$ & Globally & EFSA (2016) and FAO (2017) \\
\hline $\begin{array}{l}\text { Fish } \\
\text { Crustaceans } \\
\text { Molluscs }\end{array}$ & $\begin{array}{l}15.21 \mathrm{~kg} / \text { year } \\
2.06 \mathrm{~kg} / \text { year } \\
2.65 \mathrm{~kg} / \text { year }\end{array}$ & $\begin{array}{l}31-8323 \mathrm{MP} / \\
\text { year } \\
206-17,716 \mathrm{MP} / \\
\text { year } \\
0-27,825 \mathrm{MP} / \\
\text { year }\end{array}$ & $\begin{array}{l}\text { Globally } \\
\text { Globally } \\
\text { Globally }\end{array}$ & $\begin{array}{l}\text { Danopoulos et al. (2020), } \\
\text { Danopoulos et al. (2020) and } \\
\text { Danopoulos et al. (2020) }\end{array}$ \\
\hline Water & 21 & $\begin{array}{l}85 \mu \mathrm{g} / \mathrm{day} \\
1.4 \mu \mathrm{g} / \mathrm{kg} \text { bw/ } \\
\text { day }\end{array}$ & Globally & WHO (2019) \\
\hline Water & $\begin{array}{l}2.21 / \text { day } \\
\text { (women) } \\
3 \text { 1/day (men) }\end{array}$ & $\begin{array}{l}4400 \mathrm{MP} / \text { year } \\
\text { (women) } \\
5800 \mathrm{MP} / \text { year } \\
(\text { men) }\end{array}$ & Globally & Kosuth et al. (2018) \\
\hline Salt & $5 \mathrm{~g} /$ day & $1000 \mathrm{MP} /$ year & China & Yang et al. (2015) \\
\hline Salt & $3.95 \mathrm{~g} /$ day & $37 \mathrm{MP} /$ year & Globally & Karami et al. (2017b) \\
\hline Salt & $5 \mathrm{~g} /$ day & $\begin{array}{l}40.6-1085.2 \mathrm{MP} / \\
\text { year }\end{array}$ & Italy & Renzi and Blašković (2018) \\
\hline Salt & $\begin{array}{l}14.8-18.01 \mathrm{~g} / \\
\text { day }\end{array}$ & 64-302 MP/year & Turkey & Gündoğdu (2018) \\
\hline Salt & $2.3 \mathrm{~g} /$ day & 40-680 MP/year & Globally & Kosuth et al. (2018) \\
\hline Salt & $10.06 \mathrm{~g} /$ day & $\begin{array}{l}0-42,600 \mathrm{MP} / \\
\text { year (average } \\
3000)\end{array}$ & Globally & Kim et al. (2018) \\
\hline Salt & $5 \mathrm{~g} /$ day & $510 \mathrm{MP} /$ year & Spain & Iñiguez et al. (2017) \\
\hline Salt & 5 g/day & $117 \mu \mathrm{g} /$ year & India & Seth and Shriwastav (2018) \\
\hline
\end{tabular}


inside the body, being either phagocyted by macrophage $(>0.5 \mu \mathrm{m})$, endocyted $(<0.5 \mu \mathrm{m})$, cleared through splenic filtration $(>0.2 \mu \mathrm{m})$, or eliminated via kidney filtration $(<10 \mathrm{~nm})$ (Monti et al. 2015; Yoo et al. 2011). Nevertheless, it has to be underlined that microplastics in the lymph will be excreted mostly through the spleen or with faeces through bile clearance in the liver if present in the blood (Yoo et al. 2011).

Among the possible adverse effects caused by microplastic exposure, oxidative stress and alteration of the immune function, possibly leading to immune depression, are the most likely to occur (Petit et al. 2002; Schirinzi et al. 2017). This is because some of the particles can be taken up in the lymphatic system by phagocytic cells, such as macrophages, as mentioned before.

Furthermore, it has to be underlined that PVC could cause additional toxicity because of the possible leaching of vinyl chloride, an extremely toxic monomer, classified as carcinogenic, that is used in the production process of this material and makes up 50 to $100 \%$ of the polymer by weight (Lithner et al. 2011). The toxicity of plastic is likely due to the unreacted residual monomers that constitute this material, as they may induce genotoxic effects. Lithner et al. (2011) have elaborated a hazard ranking of monomers and additives that are present in plastic polymers, indicating the hazard for human health. PVC is also the type of polymer that requires the highest amount of additives followed by PP, PE, and styrenics.

In addition to possible adverse health consequences of the polymers itself, the combined exposure to plastic additives and associated co-contaminants adsorbed by the surrounding environment must be taken into consideration. Many additives, such as BPA, phthalates, nonylphenols, and PBDE, are known to have an impact in the organism they enter in contact with, mostly through a mechanism of endocrine disruption. Besides, the main harm derives from the fact that these molecules, which give plastic some specific characteristics, are not strongly bound to the polymer matrix and tend to easily leach from it.

On the other hand, persistent organic pollutants (POPs) that interact and become associated with microplastic particles could not only impact and alter endocrine functions in the organism (i.e. PCBs, PBDEs) but also promote carcinogenicity $(\mathrm{PAH})$. These outcomes mainly arise from the interaction with intracellular receptors and gene expression induction (JECFA 2016; Pocar et al. 2005). In consonance with the strength and type of interaction they have with the polymer's matrix, they could be released at different degrees.

The toxicity of dioxins and dioxin-like PCBs can be expressed through their corresponding toxic equivalency factor (TEF), implemented in the 1980s (Barnes 1991; Safe et al. 1985; Safe 1986) and later revised in 2005 (Van den Berg et al. 2006). This parameter expresses the relative toxicity of a compound in respect of a standard compound of known toxicity, the 2,3,7,8-tetrachlorodibenzo-p-dioxin (TCDD, TEF $=1$ ). The toxic equivalency quotient $(\mathrm{TEQ})$ is a value resulting from the sum of the weighted concentrations of each chemical multiplied by their TEF. Maximum uptake levels have been set for dioxin-like PCBs and dioxins in 2006 (European Commission 2006). 
Allowable concentrations are estimated as provisional maximum tolerable daily intake (PTDI), provisional tolerable weekly intake (PTWI), and provisional tolerable monthly intake (PTMI) and can be expressed as WHO-TEQ. Their values are established during the hazard characterization step, by evaluating the no observed adverse effect level (NOAEL), and indicate the amount of a chemical that can be ingested daily, weekly, or monthly over a lifetime without adverse health consequences (JECFA 1995). In 2017, the FAO conducted an exposure exercise that considered mussels as the target species of greatest interest because of their high consumption and because it is consumed with the viscera, where microplastics tend to be located. The exposure assessment took into consideration the highest concentration of microplastics in mussels, which was reported at 4 particles/g in China (EFSA 2016). According to CIFOCOss, the highest reported consumption of mussels corresponded to the Belgian elderly (P95) and was estimated to be $250 \mathrm{~g}$ per day per person. Considering that the highest concentration of microplastics reported in mussels was 4 particles/g and the highest consumption was $250 \mathrm{~g}$ of mussels, it was estimated that a portion of mussels could contain up to 1000 microplastic particles, i.e. around $9 \mu \mathrm{g}$, depending on the volume and density of the particles.

The exposure assessment on microplastics in mussels confirmed that the intake of microplastics per day was $0.15 \mu \mathrm{g} / \mathrm{kg}$ for a person of $60 \mathrm{~kg}$. These values were selected in order to describe the worst-case scenario and cover all the populations, including those at the highest risk.

Although the exposure assessment for mussels was carried out, the tolerable daily intake (TDI) for microplastic particles and most of its compounds has not yet been established; therefore, it is not possible to determine if this level of exposure is safe. However, the TDI for some plastic additives such as phthalates, BPA, alkylphenols, and brominated flame retardants, as well as associated sorbed contaminants such as PCBs, PAHs, and DDT, has been established, and the exposure assessment estimation shows that the level of the compounds present in microplastics from mussels was significantly lower than the TDI. Therefore, based on these assumptions, the intake of associated chemicals from ingested plastics via seafood consumption is minor compared to the total intake from the diet (FAO 2017).

As a complement, an exposure assessment exercise of microplastics in shellfish has been carried out with updated information from the current literature and also taking into account other contaminants that were not included in the previous estimates (e.g. HCHs). Procedures and outcomes are described in the following paragraph. 


\subsubsection{Case Study: Exposure Assessment of Microplastic Additives and Associated Sorbed Contaminants via Shellfish Consumption}

Since plastic particles are more likely found in the intestinal tract, the consumption of all those seafood organisms whose GI is not removed can be the main route of exposure. Almost all shellfish are eaten whole, and in the present study, the attention is focused on mussels, shrimps, prawns, clams, and oysters. Data on daily seafood consumption were taken from the Chronic Individual Food Consumption Database (CIFOCOss) of the WHO. In order to perform an exposure assessment, countries reporting the highest consumption levels of shellfish were selected. These countries were China and Finland (mussels, clams, oysters) and the Netherlands (shrimps and prawns). Only the P95 consumers, meaning top consumers of these products from each country, were considered. The adults and elderly category presented the highest daily consumption levels (g/day).

Information about microplastic load in shellfish was taken from scientific papers, only considering the highest detected amount, described in Table 8.3. Plastic materials were assumed to be spherical with a diameter of $25 \mu \mathrm{m}$, which was among the most common plastic sizes found in a study by Van Cauwenberghe and Janssen (2014) in mussels. With this information, it was possible to calculate the volume of plastic particles. The density of polymers was taken from scientific papers and reviews, and only maximum values were considered (Andrady 2017; Avio et al. 2017). By knowing the volume and the density, it was then possible to determine the weight of each plastic polymer.

Data on microplastic contamination in bivalve molluscs were taken for clams (Scapharca subcrenata), mussels (Mytilus galloprovincialis), and oysters (Saccostrea cucullata) from three studies on commercial species (Table 8.3). For these species, the highest plastic load was estimated to be $10.5,12.8$, and 7.2 particles/g wet weight, respectively (DING et al. 2018; Li et al. 2015, 2018a). In addition to these, information on shrimp contamination were taken from a recent study, where up to 4.88 particles/g tissue (wet weight) were found in commercial brown shrimp (Metapenaeus monoceros) (Hossain et al. 2020).

Indirect exposure to microplastic-bound pollutants was estimated by using the highest reported contamination levels of plastic particles found in field studies (Tables 8.1 and 8.2). These data were used to provide an estimate of exposure to microplastic-bound contaminants through the consumption of shellfish.

The exposure assessment estimation consists of several steps. First, the maximum load of microplastics in shellfish (particles/g) was multiplied by the daily dietary intake of each commodity, or consumer P95 (g/day), thus measuring the total number of particles ingested every day. This result was then multiplied by the weight of each polymeric particle derived before, in order to obtain the estimated consumption of plastic per day (g/day). Then, this value was multiplied by the maximum concentration of each contaminant $(\mathrm{ng} / \mathrm{g}$ ) reported in field studies. With these estimations, it was possible to establish the daily intake of pollutants (ng/day) 
which, converted in picograms (pg) and divided by the average body weight of an adult $(60 \mathrm{~kg})$, would finally provide information on the daily dietary exposure to environmental contaminants mediated by microplastics ( $\mathrm{pg} / \mathrm{kg}$ bw/day). This information is presented by commodity and polymer type in Table 8.5. The calculations were made based on the assumption that these chemicals were completely released from the microplastic particles.

The highest exposure to environmental contaminants associated with microplastics and plastic additives, as estimated in the present case study, could derive from the consumption of oysters, followed by mussels, clams, and finally shrimps and prawns (Table 8.5). This could cause concern because the three most contaminated shellfish groups are also the ones that are eaten whole, whereas shrimps are peeled, and most microplastics are removed.

Overall, nonylphenols are the group of xenobiotics that presented the highest microplastic-mediated exposure concentrations, which ranged from $0.25 \mathrm{ng} / \mathrm{kg} \mathrm{bw} /$ day in PP and LDPE-contaminated shrimps to $2.33 \mathrm{ng} / \mathrm{kg}$ bw/day in PVCcontaminated mussels. These high levels can most likely be related to the use of this additive in the manufacture of plastics. After NPs, PAHs are the class of environmental pollutants that could bring out the highest harm through shellfish consumption, with a concentration ranging from $4.15 \mathrm{pg} / \mathrm{kg}$ bw/day in PP-contaminated shrimps to $39.26 \mathrm{pg} / \mathrm{kg}$ bw/day in PVC-contaminated mussels. Contrariwise, according to the present results, $\mathrm{HCHs}$ could be classified as the compounds whose sorbed concentration levels on microplastics could pose the least concern. In fact, the daily dietary exposure to $\mathrm{HCHs}$ varied from $0.00 \mathrm{pg} / \mathrm{kg}$ bw/day to $0.03 \mathrm{pg} / \mathrm{kg}$ bw/day, at maximum.

The results of the exercise demonstrate that polypropylene (PP) is the polymer that might raise the least concern when analysing microplastic-mediated exposure to xenobiotics, while PVC might be the most hazardous. Despite this, the dietary exposure to environmental contaminants on ingested plastics, as calculated in the present case study, can be considered negligible, compared to other sources. Also, there is still not enough clarity on tissue transfer dynamics and concentration of chemicals associated with microplastics, which can be influenced by factors as a fugacity gradient, so this can be considered as an estimate. In conclusion, when considering the outcomes of the present exercise, it is important to also keep into account the physical-chemical properties of each polymer type, as they could also influence the sorption/desorption of chemicals and then their concentration on the microplastics.

In addition to the previous analysis, China and Finland seafood consumption values were used to perform an estimate of the total dietary exposure to organic pollutants through shellfish consumption (Table 8.6). These two countries were chosen because they represent the ones with the highest shellfish consumption levels.

When only these two countries are considered in the analysis, the exposure levels to microplastic-associated contaminants seem to be higher. PVC is again the plastic polymer that can apparently cause the most significant exposure to environmental contaminants in organisms after consumption, followed by PET, PA, PS, HDPE, LDPE, and finally PP. Anyway, PVC is generally reported to sorb pollutants to a 
Table 8.5 Overall maximum dietary exposure (pg/kg/day) of MP additives and associated sorbed pollutants resulting from the consumption of the four shellfish groups in the Netherlands, Finland, and China (age class: adults and elderly). Results are categorized by polymer type

\begin{tabular}{|c|c|c|c|c|c|c|c|c|}
\hline Polymer & Seafood & $\begin{array}{l}\text { MP-PAH } \\
\text { (pg/kg } \\
\text { bw/day) }\end{array}$ & $\begin{array}{l}\text { MP-PCB } \\
\text { (pg/kg } \\
\text { bw/day) }\end{array}$ & $\begin{array}{l}\text { MP-DDT } \\
\text { (pg/kg } \\
\text { bw/day) }\end{array}$ & $\begin{array}{l}\text { MP-PBDE } \\
\text { (pg/kg bw/ } \\
\text { day) }\end{array}$ & $\begin{array}{l}\text { MP-HCH } \\
\text { (pg/kg } \\
\text { bw/day) }\end{array}$ & $\begin{array}{l}\text { MP-BPA } \\
\text { (pg/kg } \\
\text { bw/day) }\end{array}$ & $\begin{array}{l}\text { MP- } \\
\text { NP } \\
\text { (ng/ } \\
\mathrm{kg} \\
\mathrm{bw} / \\
\text { day) }\end{array}$ \\
\hline \multirow[t]{4}{*}{ HDPE } & $\begin{array}{l}\text { Shrimps } \\
\text { and } \\
\text { prawns }\end{array}$ & 4.42 & 0.28 & 0.11 & 0.98 & 0.00 & 0.07 & 0.26 \\
\hline & Mussels & 26.26 & 1.67 & 0.64 & 5.81 & 0.02 & 0.43 & 1.56 \\
\hline & Oysters & 19.20 & 1.22 & 0.47 & 4.25 & 0.02 & 0.31 & 1.14 \\
\hline & Clams & 6.94 & 0.44 & 0.17 & 1.53 & 0.01 & 0.11 & 0.41 \\
\hline \multirow[t]{4}{*}{ LDPE } & $\begin{array}{l}\text { Shrimps } \\
\text { and } \\
\text { prawns }\end{array}$ & 4.24 & 0.27 & 0.10 & 0.94 & 0.00 & 0.07 & 0.25 \\
\hline & Mussels & 25.18 & 1.61 & 0.62 & 5.57 & 0.02 & 0.41 & 1.50 \\
\hline & Oysters & 18.41 & 1.17 & 0.45 & 4.07 & 0.02 & 0.30 & 1.09 \\
\hline & Clams & 6.65 & 0.42 & 0.16 & 1.47 & 0.01 & 0.11 & 0.39 \\
\hline \multirow[t]{4}{*}{$\mathrm{PA}$} & $\begin{array}{l}\text { Shrimps } \\
\text { and } \\
\text { prawns }\end{array}$ & 5.24 & 0.33 & 0.13 & 1.16 & 0.00 & 0.09 & 0.31 \\
\hline & Mussels & 31.14 & 1.98 & 0.76 & 6.89 & 0.03 & 0.51 & 1.85 \\
\hline & Oysters & 22.76 & 1.45 & 0.56 & 5.03 & 0.02 & 0.37 & 1.35 \\
\hline & Clams & 8.23 & 0.52 & 0.20 & 1.82 & 0.01 & 0.13 & 0.49 \\
\hline \multirow[t]{4}{*}{ PS } & $\begin{array}{l}\text { Shrimps } \\
\text { and } \\
\text { prawns }\end{array}$ & 5.06 & 0.32 & 0.12 & 1.12 & 0.00 & 0.08 & 0.30 \\
\hline & Mussels & 30.05 & 1.92 & 0.74 & 6.65 & 0.02 & 0.49 & 1.78 \\
\hline & Oysters & 21.97 & 1.40 & 0.54 & 4.86 & 0.02 & 0.36 & 1.30 \\
\hline & Clams & 7.94 & 0.51 & 0.19 & 1.76 & 0.01 & 0.13 & 0.47 \\
\hline \multirow[t]{4}{*}{$\mathrm{PP}$} & $\begin{array}{l}\text { Shrimps } \\
\text { and } \\
\text { prawns }\end{array}$ & 4.15 & 0.26 & 0.10 & 0.92 & 0.00 & 0.07 & 0.25 \\
\hline & Mussels & 26.64 & 1.57 & 0.60 & 5.45 & 0.02 & 0.40 & 1.46 \\
\hline & Oysters & 18.01 & 1.15 & 0.44 & 3.98 & 0.01 & 0.29 & 1.07 \\
\hline & Clams & 6.51 & 0.41 & 0.16 & 1.44 & 0.01 & 0.11 & 0.39 \\
\hline \multirow[t]{4}{*}{$\mathrm{PVC}$} & $\begin{array}{l}\text { Shrimps } \\
\text { and } \\
\text { prawns }\end{array}$ & 6.61 & 0.42 & 0.16 & 1.46 & 0.01 & 0.11 & 0.39 \\
\hline & Mussels & 39.26 & 2.50 & 0.96 & 8.68 & 0.03 & 0.64 & 2.33 \\
\hline & Oysters & 28.70 & 1.83 & 0.70 & 6.35 & 0.02 & 0.47 & 1.70 \\
\hline & Clams & 10.37 & 0.66 & 0.25 & 2.29 & 0.01 & 0.17 & 0.62 \\
\hline
\end{tabular}


Table 8.5 (continued)

\begin{tabular}{|c|c|c|c|c|c|c|c|c|}
\hline Polymer & Seafood & $\begin{array}{l}\text { MP-PAH } \\
\text { (pg/kg } \\
\text { bw/day) }\end{array}$ & $\begin{array}{l}\text { MP-PCB } \\
\text { (pg/kg } \\
\text { bw/day) }\end{array}$ & $\begin{array}{l}\text { MP-DDT } \\
\text { (pg/kg } \\
\text { bw/day) }\end{array}$ & $\begin{array}{l}\text { MP-PBDE } \\
\text { (pg/kg bw/ } \\
\text { day) }\end{array}$ & $\begin{array}{l}\text { MP-HCH } \\
\text { (pg/kg } \\
\text { bw/day) }\end{array}$ & $\begin{array}{l}\text { MP-BPA } \\
\text { (pg/kg } \\
\text { bw/day) }\end{array}$ & $\begin{array}{l}\text { MP- } \\
\mathrm{NP} \\
\text { (ng/ } \\
\mathrm{kg} \\
\mathrm{bw} / \\
\text { day) }\end{array}$ \\
\hline \multirow[t]{4}{*}{ PET } & $\begin{array}{l}\text { Shrimps } \\
\text { and } \\
\text { prawns }\end{array}$ & 6.38 & 0.41 & 0.16 & 1.41 & 0.01 & 0.10 & 0.38 \\
\hline & Mussels & 37.90 & 2.42 & 0.93 & 8.38 & 0.03 & 0.62 & 2.25 \\
\hline & Oysters & 27.71 & 1.77 & 0.68 & 6.13 & 0.02 & 0.45 & 1.65 \\
\hline & Clams & 10.01 & 0.64 & 0.25 & 2.21 & 0.01 & 0.16 & 0.59 \\
\hline
\end{tabular}

Table 8.6 Overall dietary exposure to MP additives and associated sorbed pollutants in Finland and China (age class: adults and elderly) resulting from shellfish consumption. Data on food consumption were taken from WHO CIFOCOss. Results are presented as overall exposure concentrations resulting from the combination of the four shellfish groups (mussels, oysters, clams, and shrimps and prawns), categorized by polymer type

\begin{tabular}{|c|c|c|c|c|c|c|c|c|}
\hline Polymer & Country & $\begin{array}{l}\text { MP-PAH } \\
\text { (pg/kg } \\
\text { bw/day) }\end{array}$ & $\begin{array}{l}\text { MP-PCB } \\
\text { (pg/kg } \\
\text { bw/day) }\end{array}$ & $\begin{array}{l}\text { MP-DDT } \\
\text { (pg/kg } \\
\text { bw/day) }\end{array}$ & $\begin{array}{l}\text { MP-PBDE } \\
\text { (pg/kg bw/ } \\
\text { day) }\end{array}$ & $\begin{array}{l}\text { MP-HCH } \\
\text { (pg/kg } \\
\text { bw/day) }\end{array}$ & $\begin{array}{l}\text { MP-BPA } \\
\text { (pg/kg } \\
\text { bw/day) }\end{array}$ & $\begin{array}{l}\text { MP- } \\
\mathrm{NP} \\
\text { (ng/ } \\
\mathrm{kg} \\
\mathrm{bw} / \\
\text { day) }\end{array}$ \\
\hline \multirow[t]{2}{*}{ HDPE } & China & 41.52 & 2.65 & 1.02 & 9.18 & 0.03 & 0.68 & 2.47 \\
\hline & Finland & 22.43 & 1.43 & 0.55 & 4.96 & 0.02 & 0.37 & 1.33 \\
\hline \multirow{2}{*}{ LDPE } & China & 39.81 & 2.54 & 0.98 & 8.80 & 0.03 & 0.65 & 2.36 \\
\hline & Finland & 21.51 & 1.37 & 0.53 & 4.76 & 0.02 & 0.35 & 1.28 \\
\hline \multirow[t]{2}{*}{ PA } & China & 49.22 & 3.14 & 1.21 & 10.89 & 0.04 & 0.80 & 2.92 \\
\hline & Finland & 26.60 & 1.70 & 0.65 & 5.88 & 0.02 & 0.43 & 1.58 \\
\hline \multirow[t]{2}{*}{ PS } & China & 47.51 & 3.03 & 1.17 & 10.51 & 0.04 & 0.77 & 2.82 \\
\hline & Finland & 25.67 & 1.64 & 0.63 & 5.68 & 0.02 & 0.42 & 1.52 \\
\hline \multirow[t]{2}{*}{ PP } & China & 38.95 & 2.48 & 0.96 & 8.62 & 0.03 & 0.63 & 2.31 \\
\hline & \begin{tabular}{|l|} 
Finland \\
\end{tabular} & 21.05 & 1.34 & 0.52 & 4.65 & 0.02 & 0.34 & 1.25 \\
\hline \multirow[t]{2}{*}{ PVC } & China & 62.06 & 3.96 & 1.52 & 13.73 & 0.05 & 1.01 & 3.68 \\
\hline & Finland & 33.53 & 2.14 & 0.82 & 7.42 & 0.03 & 0.55 & 1.99 \\
\hline \multirow[t]{2}{*}{ PET } & China & 59.92 & 3.82 & 1.47 & 13.25 & 0.05 & 0.98 & 3.56 \\
\hline & Finland & 32.38 & 2.06 & 0.79 & 7.16 & 0.03 & 0.53 & 1.92 \\
\hline
\end{tabular}

lower amount compared to rubbery plastics and especially to PE. Our calculations, in fact, analyse the sorptive capacities of plastic materials by only taking into consideration their densities and not their physico-chemical properties. With respect to this, it should be noted that cooking and food processing can sometimes lead to physicochemical changes in the plastic particles. A recent study has measured a reduction of approximately $14 \%$ of microplastics in cooked mussels, with also a 
possible size reduction of the particles (Renzi et al. 2018). Moreover, high temperatures could also enhance the release of chemical compounds from microplastics (Bach et al. 2013).

Finally, it is now possible to compare the results of the exposure assessment of associated chemicals from ingested plastics via seafood consumption (Table 8.5; Table 8.6) with the no observed effect levels (NOELs) and no observed adverse effect levels (NOAELs) established by international expert committees such as the Joint FAO/WHO Expert Committee on Food Additives (JECFA) or EFSA (Table 8.7). The purpose of this last step is to check whether the highest load of microplastic-bound pollutants could lead to a significant threat to humans after the consumption of shellfish or not.

The NOEL values are not indicative of the tolerable daily intake (TDI) of contaminants but can provide useful information on the threshold of toxicological concern. In the present case study, the dietary exposures to MP-bound pollutant concentrations were in the order of nanograms ( $\mathrm{ng} / \mathrm{kg}$ bw/day), well below the NOELs set by the literature.

PAHs can be metabolized, resulting in genotoxic effects and carcinogenicity, especially the ones presenting a higher number of aromatic rings (Scientific Committee on Food 2002b). For this reason, no TDI can be estimated. Mean and high daily intake in adults have been estimated to be 4 and $10 \mathrm{ng} / \mathrm{kg}$ bw, with children exposure being more than twofolds higher (JECFA 2006a). Benzo(a)pyrene can be used as a marker of PAH contamination in food, but the sum of benzo[a]pyrene and chrysene (PAH2); the sum of benzo[a]pyrene, chrysene, benz[a]anthracene, and benzo[b]fluoranthene (PAH4); and the sum of benzo[a]pyrene, benz[a]anthracene, benzo[b]fluoranthene, benzo[k]fluoranthene, benzo[ghi]perylene, chrysene, dibenz[a,h]anthracene, and indeno[1,2,3-cd]pyrene (PAH8) have been suggested as

Table 8.7 No observed effect levels (NOELs), benchmark dose lower confidence limit (BMDL), no observed adverse effect levels (NOAELs), allowable daily intake (ADI), and tolerable daily intake (TDI) values established by international authorities

\begin{tabular}{l|l|l|l}
\hline Chemical & NOEL /NOAEL/BMDL & ADI/TDI & Source \\
\hline PCBs & $0.04 \mathrm{mg} / \mathrm{kg}$ bw/day & $20 \mathrm{ng} / \mathrm{kg}$ bw & $\begin{array}{l}\text { Faroon et al. (2003) and } \\
\text { JECFA (1990) }\end{array}$ \\
\hline PAHs & $\begin{array}{l}0.17 \text { (PAH2), 0.34 } \\
\text { (PAH4),0.49 (PAH8) } \mathrm{mg} / \mathrm{kg} \\
\text { bw }\end{array}$ & $\begin{array}{l}\text { Not established, } \\
\text { carcinogen }\end{array}$ & EFSA (2008) \\
\hline $\begin{array}{l}\text { Benzo(a) } \\
\text { pyrene }\end{array}$ & $100 \mu \mathrm{g} / \mathrm{kg}$ bw & $\begin{array}{l}\text { Not established, } \\
\text { carcinogen }\end{array}$ & JECFA (2006b) \\
\hline$\gamma$-HCH & $0.47 \mathrm{mg} / \mathrm{kg}$ bw/day & $0-0.005 \mathrm{mg} / \mathrm{kg} \mathrm{bw}$ & JECFA (2002) \\
\hline DDT & $1 \mathrm{mg} / \mathrm{kg}$ bw/day & $0.01 \mathrm{mg} / \mathrm{kg} \mathrm{bw}$ & JECFA (2001) \\
\hline PBDEs & Not established & Not established & JECFA (2006c) \\
\hline BPA & $5 \mathrm{mg} / \mathrm{kg}$ bw/day & $4 \mu \mathrm{g} / \mathrm{kg}$ bw & $\begin{array}{l}\text { EFSA (2015) and Scientific } \\
\text { Committee on Food (2002a) }\end{array}$ \\
\hline NP & $15 \mathrm{mg} / \mathrm{kg} / \mathrm{day}$ & $5 \mu \mathrm{kg}$ bw & $\begin{array}{l}\text { Bontje et al. (2004) and } \\
\text { Nielsen et al. (2000) }\end{array}$ \\
\hline
\end{tabular}


more suitable alternatives, with the last two parameters being the most appropriate markers for genotoxic and carcinogenic PAHs in food commodities (EFSA 2008).

For DDT, the no observed effect level (NOEL) and provisional tolerable daily intake (PTDI) are $1 \mathrm{mg} / \mathrm{kg}$ bw/day and $0-0.01 \mathrm{mg} / \mathrm{kg}$ bw/day, respectively, with the highest observed average intake of $0.68 \mathrm{mg} / \mathrm{man} /$ day (JECFA 1961).

The tolerable daily intake (TDI) temporarily established for BPA in foodstuff was set as $4 \mu \mathrm{g} / \mathrm{kg}$ bw/day (EFSA 2015), and the daily intake in adults in Europe has been estimated up to $1.5 \mu \mathrm{g} / \mathrm{kg}$ bw (Scientific Committee on Food 2002a). As it concerns intake for nonylphenol, the TDI was estimated at $5 \mu \mathrm{g} / \mathrm{kg}$ bw/day by the Danish Institute of Safety and Toxicology (Nielsen et al. 2000). It can be concluded that the levels of microplastic-bound contaminants found in the selected commodities (shrimp, prawns, clams, oyster, and mussels) are below the ones reported in Table 8.7. Based on these estimation values, it could be assumed that the transfer of environmental pollutants and additives mediated by microplastic particles in shellfish is negligible. In fact, the contribution made by other sources such as the ingestion of contaminated prey items and subsequent transfer of POPs from food to organism supplies most of the contaminant burden (FAO 2017). However, emerging additives from MP should be further explored, and plasticizer additives such as phthalates and organophosphate flame retardants have not yet been investigated.

\subsubsection{Limitations for Food Safety Risk Assessment}

The fate of plastic in the human body and its possible food safety impact are unknown. Although it is thought that the particles below $1.5 \mu \mathrm{m}$ can penetrate into the capillaries of the organs, while larger particles will be excreted (Yoo et al. 2011), there are many knowledge gaps such as toxicological data of commonly ingested plastics and its compounds.

The best-studied dietary sources of microplastics are fisheries and aquaculture products, which are important food commodities in certain areas. However, the toxicity of most plastic monomers, polymers, and additives present in microplastics has never been evaluated by relevant international expert scientific committees such as the JECFA. International expert committees such as the JECFA are key to evaluate the potential toxicity, considering newly generated scientific data and establishing the basis for the risk analysis exercises (risk assessment, risk management, and risk communication (Fig. 8.1)).

In order to perform a proper exposure and then risk assessment of plastic particles, and plastic as a vector of additives and associated sorbed pollutants, researchers should develop new techniques to better understand toxicity and transfer mechanisms. In addition to that, improvement should be made to detect smaller plastic fragments, especially those in the range of the nanoparticles, which are not much studied. These are, in fact, the ones that could mostly enhance negative consequences on the organism both because of their ability to cross biological barriers and their higher sorption capacity. 


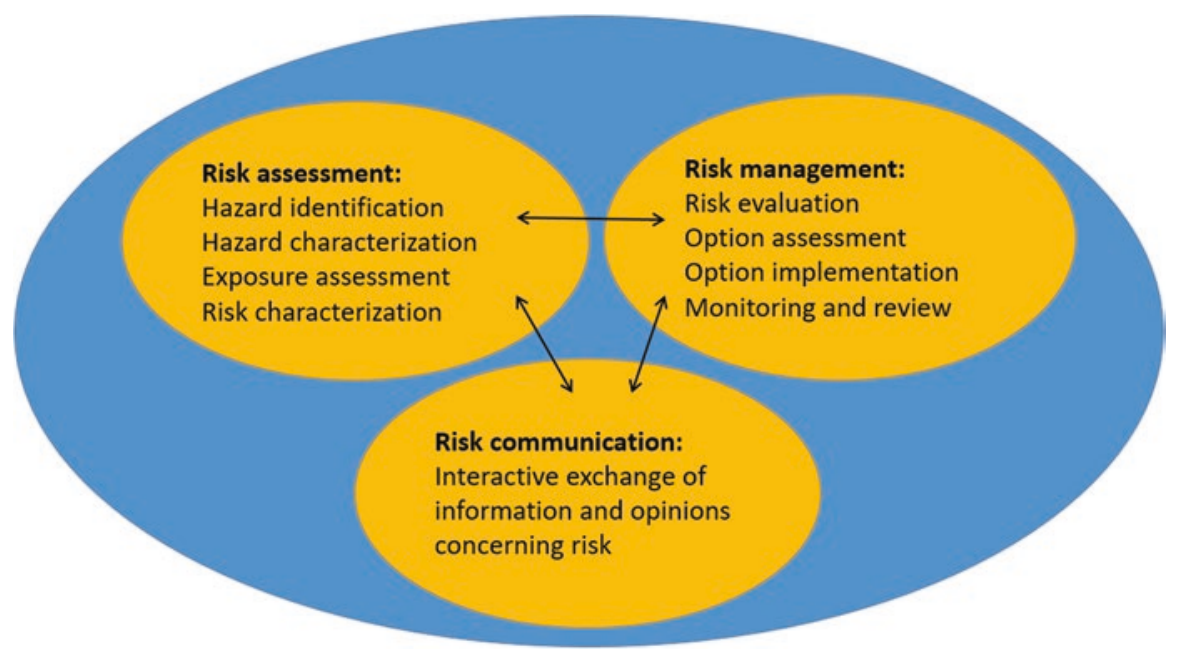

Fig. 8.1 FAO/WHO risk analysis framework. (Adapted from FAO 2017)

\subsection{Research Gaps}

Although most microplastics are found in the gastrointestinal tract of aquatic animals, there is a limited understanding of the presence of microplastics and specially nanoplastics in edible parts of fisheries and aquaculture products. This mainly occurs because there are no standard methodologies to analyse plastic particles in foods. While many researchers are developing analytical methods, there are still research gaps:

- Standard tissue digestion and polymer identification and quantification protocols should be determined.

- Future research should focus more on nanoplastics, which may also be the ones eliciting the highest exposure due to their size.

- As some particles have been found in the edible tissues of fish, future studies should also include muscle analysis.

- More studies should focus their attention on other food commodities that could be contaminated by microplastics, such as table salt or seaweed.

- More investigations on additive leaching and contaminant desorption processes under gut conditions should be carried out, to understand the exposure to xenobiotic chemicals through plastic ingestion.

Data that would allow a food safety risk assessment is limited and the consequences of microplastic exposure through diet are poorly understood. Most studies have investigated the effects of the inhalation of plastic particles, and very few of them analysed the consequences of a dietary uptake. As it concerns the risk assessment of microplastics, the following research gaps were identified: 
- Chronic exposure to microplastics and nanoplastics in humans via ingestion, inhalation and, skin contact should be carried out.

- Environmentally relevant concentrations of plastics, their additives, and sorbed pollutants should be used in dose-response assays for a better understanding of their toxicity.

- The exposure to microorganisms present on plastic debris should be evaluated, as some pathogens might also be found on them.

- Consequences of the dietary intake of different concentrations of plastic additives, monomers, and contaminants should be clarified, as many of these chemicals might trigger response mechanisms even at low doses.

- Changes in the structure and chemical composition of microplastics and nanoplastics in foods while processing or cooking, as well as their interaction with the food matrix, should be further studied.

- Once the consequences of microplastic exposure through diets are clarified, mechanisms of control should be put in place.

\subsection{Conclusions}

Micro- and nanoscale plastic particles are widely distributed in the aquatic environment, and aquatic animals are exposed to them, which results in the presence of microplastics and nanoplastics in fisheries and aquaculture commodities.

Most microplastics and nanoplastics are found in the gastrointestinal tract of aquatic species, and evisceration could lead to a substantial decrease in the exposure to plastics in the final consumer. Nevertheless, there are fisheries and aquaculture commodities such as small fish, crustaceans, and bivalve mollusc that are commonly consumed whole, so the exposure through these products is higher.

There is evidence of a sorptive behaviour of microplastics and nanoplastics, which has been observed both in the laboratory and in the field. Because of their hydrophobicity and high surface/volume, plastic polymers can concentrate organic contaminants by several folds compared to the water column and might also host biofilm-forming microorganisms on their surface.

Microplastic contaminants and additives added during the manufacturing process to add specific features of the final product have been found to have adverse effects on humans and animals, mostly related to carcinogenicity and reproductive toxicity.

Data on human dietary intake of microplastics are very scarce. An exposure assessment was carried out to evaluate human exposure to environmental contaminants and plastic additives through microplastic-contaminated seafood. The worstcase estimate of the exposure to contaminants through seafood indicates the contribution of microplastic contaminants, and additives through fisheries and aquaculture products are negligible compared to other sources. Besides, the exposure scenario assumed the complete release of contaminants and additives once in the 
gut, which is unlikely. Moreover, even in this case, the levels of xenobiotics were several orders of magnitude lower than threshold values (NOAEL) indicated by international authorities.

Microplastic dietary intake for other food commodities such as salt or water should be carried out to understand the overall exposure through food and open the possibility for food safety risk assessment.

Literature on the actual effect of microplastics and nanoplastics in humans is extremely poor, and more research is needed to understand the toxicity of the most common polymers and plastic additives, as well as their mixture.

\subsection{Glossary}

\subsubsection{Microplastics and Nanoplastics Definition}

Recently, many studies have focused their attention on the possible harm caused by micro- and nano-sized plastic particles on human and animal health. The size of the particles seems to be one of the main aspects to possibly pose a food safety threat.

There is an ongoing debate about how to define micro- and nanoplastic particles. One of the most accepted definition describes them as plastic particles consisting of a heterogeneous mixture of different shaped materials in the range from $0.1 \mu \mathrm{m}$ to $5000 \mu \mathrm{m}$ in their longest dimensions (EFSA 2016; Lusher et al. 2017), while nanoplastics are defined as plastic particles whose size ranges from $0.001 \mu \mathrm{m}$ to $0.1 \mu \mathrm{m}$ (Klaine et al. 2012).

Plastics can also be classified according to the process that generated them. Primary microplastics are intentionally produced (e.g. plastic and/or cosmetics manufacture), while secondary microplastics are the result of fragmentation of larger materials are discharged into the environment (GESAMP 2015).

\subsubsection{Microplastics and Nanoplastics Composition}

Depending on the intended use, polymers with different physical and chemical properties can be mixed. Additionally, additives such as plasticizers, flame retardants, colourants, or antioxidants are normally included in various percentages to improve their performance. When plastics reach the environment, they can also sorb and accumulate many hydrophobic environmental contaminants, being a potential vector for additives and sorbed contaminants to the organisms. Among the sorbed hydrophobic pollutants are polychlorinated biphenyls (PCBs), polycyclic aromatic hydrocarbons (PAHs), and chlorinated pesticides, all of them belonging to the group of persistent organic pollutants (POPs), as they are persistent, bioaccumulative, and 
toxic (PBT) substances. Trace metals and microorganisms such as pathogenic bacteria or viruses might also sorb on microplastics (FAO 2017; GESAMP 2016).

\subsubsection{Monomers and Polymers}

Monomers such as ethylene, propylene, and styrene are the building blocks of polymers that lead to the production of a variety of materials. The most common polymers are acrylonitrile butadiene styrene (ABS), acrylic, epoxy resin, expanded polystyrene (EPS), polyethylene high density (HDPE), polyethylene low density (LDPE), polycarbonate, polycaprolactone, polyethylene (PE), polyethylene terephthalate (PET), poly (glycolic) acid, poly(lactide), poly(methyl methacrylate), polypropylene (PP), polystyrene (PS), polyurethane, polyethylene linear low density, polyamide (Nylon) 4, 6, 11, 66 (PA), polyvinyl alcohol, polyvinyl chloride (PVC), styrene-butadiene rubber, and thermoplastic polyurethane (FAO 2017). All these monomers and polymers can be expected to be part of microplastic particles present in the environment and therefore enter different food value chains.

\subsubsection{Flame Retardants}

Today, there are more than 175 chemicals classified as flame retardants (FRs) (Alaee et al. 2003). Some of these compounds are commonly added to polymers to reduce their flammability. Polybrominated diphenyl ethers (PBDEs) and hexabromocyclododecanes (HBCDs) are the most utilized brominated FRs in plastic manufacture and are commonly added to polystyrene, polyesters, polyolefins, polyamides, epoxies, and ABS. Some HBCDs and PBDEs are simply blended with the polymers and therefore are more likely to leach out of the products, while others can be incorporated into the polymers (Hutzinger and Thoma 1987), a consequence that poses an environmental and food safety concern. PBDEs and HBCD are listed by the Stockholm Convention as Persistent Organic Pollutants (POPs) and are associated with hepatotoxicity, kidney toxicity, endocrine-disrupting effects, and teratogenicity (Muirhead et al. 2006; Yogui and Sericano 2009). Nowadays, organophosphorus flame retardants (OPFRs) are extensively used as additives in order to replace the brominated ones. These compounds have been seen to induce toxicity in vitro and in vivo up to a certain degree (e.g. oxidative stress, cytotoxicity, endocrine disruption), but information on their accumulation and biomagnification in the food chain is still scarce (reviewed by Du et al. 2019).

\subsubsection{Plasticizers}

Substances such as phthalates and BP are used to enhance flexibility and softness and to reduce brittleness. These chemicals are usually added to synthetic polymers used in food packaging such as polycarbonate and epoxy resins but also PE, PP, and/ 
or PVC (EFSA 2007; FAO/WHO 2009). Both phthalates and BPA have been found to act as endocrine disruptors, causing fertility problems, cardiovascular diseases, development disorders, and reproductive cancers, while the toxicity of other BPs either remains unknown or information is not sufficient (Chen et al. 2016; Ma et al. 2019; Rochester 2013).

\subsubsection{Antioxidants and Stabilizers}

Nonylphenols (NPs) are a group of organic compounds belonging to the family of alkylphenols and are extensively used as a stabilizer in food packaging and as antioxidants in polymers such as rubber, vinyl, polyolefins, polystyrenes, and PVC (GESAMP 2016; USEPA 2010). NPs are known to be endocrine disruptors and have been reported to exert synergistic effects following their co-occurrence with other compounds (Soares et al. 2008; Vethaak et al. 2005).

\section{References}

Abbasi S, Soltani N, Keshavarzi B, Moore F, Turner A, Hassanaghaei M (2018) Microplastics in different tissues of fish and prawn from the Musa Estuary, Persian Gulf. Chemosphere. https:// doi.org/10.1016/j.chemosphere.2018.04.076

Abdelouahab N, Suvorov A, Pasquier JC, Langlois MF, Praud JP, Takser L (2009) Thyroid disruption by low-dose BDE-47 in prenatally exposed lambs. Neonatology. https://doi. org/10.1159/000209316

Ahrens MJ, Hertz J, Lamoureux EM, Lopez GR, McElroy AE, Brownawell BJ (2001) The role of digestive surfactants in determining bioavailability of sediment-bound hydrophobic organic contaminants to 2 deposit-feeding polychaetes. Mar Ecol Prog Ser 212:145-157. https://doi. org/10.3354/meps 212145

Akhbarizadeh R, Moore F, Keshavarzi B (2018) Investigating a probable relationship between microplastics and potentially toxic elements in fish muscles from northeast of Persian Gulf. Environ Pollut 232:154-163. https://doi.org/10.1016/j.envpol.2017.09.028

Alaee M, Arias P, Sjödin A, Bergman $\AA$ (2003) An overview of commercially used brominated flame retardants, their applications, their use patterns in different countries/regions and possible modes of release. Environ Int. https://doi.org/10.1016/S0160-4120(03)00121-1

Andrade C, Ovando F (2017) First record of microplastics in stomach content of the southern king crab Lithodes santolla (Anomura: Lithodidae), Nassau bay, Cape Horn, Chile. An del Inst la Patagon 45:59-65. https://doi.org/10.4067/s0718-686x2017000300059

Andrady AL (2011) Microplastics in the marine environment. Mar Pollut Bull 62:1596-1605. https://doi.org/10.1016/j.marpolbul.2011.05.030

Andrady AL (2017) The plastic in microplastics: a review. Mar Pollut Bull 119:12-22. https://doi. org/10.1016/j.marpolbul.2017.01.082

Antunes JC, Frias JGL, Micaelo AC, Sobral P (2013) Resin pellets from beaches of the Portuguese coast and adsorbed persistent organic pollutants. Estuar Coast Shelf Sci 130:62-69. https://doi. org/10.1016/j.ecss.2013.06.016

Ashton K, Holmes L, Turner A (2010) Association of metals with plastic production pellets in the marine environment. Mar Pollut Bull 60:2050-2055. https://doi.org/10.1016/j. marpolbul.2010.07.014 
Avio CG, Gorbi S, Milan M, Benedetti M, Fattorini D, D'Errico G, Pauletto M, Bargelloni L, Regoli F (2015) Pollutants bioavailability and toxicological risk from microplastics to marine mussels. Environ Pollut 198:211-222. https://doi.org/10.1016/j.envpol.2014.12.021

Avio CG, Gorbi S, Regoli F (2017) Plastics and microplastics in the oceans: from emerging pollutants to emerged threat. Mar Environ Res 128:2-11. https://doi.org/10.1016/j. marenvres.2016.05.012

Baalkhuyur FM, Bin Dohaish E-JA, Elhalwagy MEA, Alikunhi NM, AlSuwailem AM, Røstad A, Coker DJ, Berumen ML, Duarte CM (2018) Microplastic in the gastrointestinal tract of fishes along the Saudi Arabian Red Sea coast. Mar Pollut Bull 131:407-415. https://doi.org/10.1016/j. marpolbul.2018.04.040

Bach C, Dauchy X, Severin I, Munoz J-F, Etienne S, Chagnon M-C (2013) Effect of temperature on the release of intentionally and non-intentionally added substances from polyethylene terephthalate (PET) bottles into water: chemical analysis and potential toxicity. Food Chem 139:672-680. https://doi.org/10.1016/j.foodchem.2013.01.046

Barboza LGA, Cunha SC, Monteiro C, Fernandes JO, Guilhermino L (2020) Bisphenol A and its analogs in muscle and liver of fish from the North East Atlantic Ocean in relation to microplastic contamination. Exposure and risk to human consumers. J Hazard Mater. https:// doi.org/10.1016/j.jhazmat.2020.122419

Barnes DG (1991) Toxicity equivalents and EPA's risk assessment of 2,3,7,8-TCDD. Sci Total Environ 104:73-86. https://doi.org/10.1016/0048-9697(91)90008-3

Bessa F, Barría P, Neto JM, Frias JPGL, Otero V, Sobral P, Marques JC (2018) Occurrence of microplastics in commercial fish from a natural estuarine environment. Mar Pollut Bull 128:575-584. https://doi.org/10.1016/j.marpolbul.2018.01.044

Boerger CM, Lattin GL, Moore SL, Moore CJ (2010) Plastic ingestion by planktivorous fishes in the North Pacific Central Gyre. Mar Pollut Bull 60:2275-2278. https://doi.org/10.1016/j. marpolbul.2010.08.007

Bontje D, Hermens J, Vermeire T, Damstra T (2004) Integrated risk assessment: nonylphenol case study. Report prepared for the WHO/UNEP/ILO International Programme on Chemical Safety 4:64-75

Braekevelt E, Tittlemier SA, Tomy GT (2003) Direct measurement of octanol-water partition coefficients of some environmentally relevant brominated diphenyl ether congeners. Chemosphere. https://doi.org/10.1016/S0045-6535(02)00841-X

Bråte ILN, Hurley R, Iversen K, Beyer J, Thomas KV, Steindal CC, Green NW, Olsen M, Lusher A (2018) Mytilus spp. as sentinels for monitoring microplastic pollution in Norwegian coastal waters: a qualitative and quantitative study. Environ Pollut 243:383-393. https://doi. org/10.1016/j.envpol.2018.08.077

Brennecke D, Duarte B, Paiva F, Caçador I, Canning-Clode J (2016) Microplastics as vector for heavy metal contamination from the marine environment. Estuar Coast Shelf Sci. https://doi. org/10.1016/j.ecss.2015.12.003

Browne MA, Niven SJ, Galloway TS, Rowland SJ, Thompson RC (2013) Microplastic moves pollutants and additives to worms, reducing functions linked to health and biodiversity. Curr Biol 23:2388-2392. https://doi.org/10.1016/j.cub.2013.10.012

Carlson GP (1980) Induction of xenobiotic metabolism in rats by short-term administration of brominated diphenyl ethers. Toxicol Lett. https://doi.org/10.1016/0378-4274(80)90143-5

Catarino AI, Macchia V, Sanderson WG, Thompson RC, Henry TB (2018) Low levels of microplastics (MP) in wild mussels indicate that MP ingestion by humans is minimal compared to exposure via household fibres fallout during a meal. Environ Pollut. https://doi.org/10.1016/j. envpol.2018.02.069

Chagnon C, Thiel M, Antunes J, Ferreira JL, Sobral P, Ory NC (2018) Plastic ingestion and trophic transfer between Easter Island flying fish (Cheilopogon rapanouiensis) and yellowfin tuna (Thunnus albacares) from Rapa Nui (Easter Island). Environ Pollut. https://doi.org/10.1016/j. envpol.2018.08.042 
Chen D, Kannan K, Tan H, Zheng Z, Feng YL, Wu Y, Widelka M (2016) Bisphenol analogues other than. BPA: environmental occurrence, human exposure, and toxicity - a review. Environ Sci Technol. https://doi.org/10.1021/acs.est.5b05387

Cheung L, Lui C, Fok L (2018) Microplastic contamination of wild and captive flathead grey mullet (Mugil cephalus). Int J Environ Res Public Health 15:597. https://doi.org/10.3390/ ijerph15040597

Cho Y, Shim WJ, Jang M, Han GM, Hong SH (2019) Abundance and characteristics of microplastics in market bivalves from South Korea. Environ Pollut. https://doi.org/10.1016/j. envpol.2018.11.091

Chua EM, Shimeta J, Nugegoda D, Morrison PD, Clarke BO (2014) Assimilation of polybrominated diphenyl ethers from microplastics by the marine amphipod, Allorchestes compressa. Environ Sci Technol 48:8127-8134. https://doi.org/10.1021/es405717z

Colabuono FI, Taniguchi S, Montone RC (2010) Polychlorinated biphenyls and organochlorine pesticides in plastics ingested by seabirds. Mar Pollut Bull 60:630-634. https://doi. org/10.1016/j.marpolbul.2010.01.018

Collard F, Gilbert B, Compère P, Eppe G, Das K, Jauniaux T, Parmentier E (2017) Microplastics in livers of European anchovies (Engraulis encrasicolus, L.). Environ Pollut. https://doi. org/10.1016/j.envpol.2017.07.089

Danopoulos E, Jenner LC, Twiddy M, Rotchell JM (2020) Microplastic contamination of seafood intended for human consumption: a systematic review and meta-analysis. Environ Health Perspect. https://doi.org/10.1289/EHP7171

Darnerud PO, Eriksen GS, Jóhannesson T, Larsen PB, Viluksela M (2001) Polybrominated diphenyl ethers: occurrence, dietary exposure, and toxicology. Environ Health Perspect 109:49-68. https://doi.org/10.1289/ehp.01109s149

Davidson K, Dudas SE (2016) Microplastic ingestion by wild and cultured Manila clams (Venerupis philippinarum) from Baynes Sound, British Columbia. Arch Environ Contam Toxicol 71:147-156. https://doi.org/10.1007/s00244-016-0286-4

De Jong WH, Hagens WI, Krystek P, Burger MC, Sips AJAM, Geertsma RE (2008) Particle size-dependent organ distribution of gold nanoparticles after intravenous administration. Biomaterials 29:1912-1919. https://doi.org/10.1016/j.biomaterials.2007.12.037

De Witte B, Devriese L, Bekaert K, Hoffman S, Vandermeersch G, Cooreman K, Robbens J (2014) Quality assessment of the blue mussel (Mytilus edulis): comparison between commercial and wild types. Mar Pollut Bull 85:146-155. https://doi.org/10.1016/j.marpolbul.2014.06.006

Devriese LI, van der Meulen MD, Maes T, Bekaert K, Paul-Pont I, Frère L, Robbens J, Vethaak AD (2015) Microplastic contamination in brown shrimp (Crangon crangon, Linnaeus 1758) from coastal waters of the Southern North Sea and Channel area. Mar Pollut Bull 98:179-187. https://doi.org/10.1016/j.marpolbul.2015.06.051

Digka N, Tsangaris C, Torre M, Anastasopoulou A, Zeri C (2018) Microplastics in mussels and fish from the northern Ionian Sea. Mar Pollut Bull. https://doi.org/10.1016/j.marpolbul.2018.06.063

Ding J-F, Li J-X, Sun C-J, He C-F, Jiang F-H, Gao F-L, Zheng L (2018) Separation and identification of microplastics in digestive system of bivalves. Chinese J Anal Chem 46:690-697. https:// doi.org/10.1016/S1872-2040(18)61086-2

Du J, Li H, Xu S, Zhou Q, Jin M, Tang J (2019) A review of organophosphorus flame retardants (OPFRs): occurrence, bioaccumulation, toxicity, and organism exposure. Environ Sci Pollut Res 26:22126-22136. https://doi.org/10.1007/s11356-019-05669-y

EFSA (2007) Opinion of the Scientific Panel on food additives, flavourings, processing aids and materials in contact with food (AFC) related to 2,2-BIS(4-HYDROXYPHENYL) PROPANE. EFSA J 5:428. https://doi.org/10.2903/j.efsa.2007.428

EFSA (2008) Polycyclic aromatic hydrocarbons in food - scientific opinion of the panel on contaminants in the food chain. EFSA J 724:1-114. https://doi.org/10.2903/j.efsa.2008.724

EFSA (2011) Scientific opinion on Polybrominated diphenyl ethers (PBDEs) in food. EFSA J 9:1-274. https://doi.org/10.2903/j.efsa.2011.2156 
EFSA (2015) Scientific Opinion on the risks to public health related to the presence of bisphenol A (BPA) in foodstuffs. EFSA J 13:3978. https://doi.org/10.2903/j.efsa.2015.3978

EFSA (2016) Presence of microplastics and nanoplastics in food, with particular focus on seafood. EFSA J 14. https://doi.org/10.2903/j.efsa.2016.4501

Endo S, Koelmans AA (2016) Sorption of hydrophobic organic compounds to plastics in the marine environment: equilibrium. In: Hazardous chemicals associated with plastics in the marine environment, Handbook of environmental chemistry. Springer, Cham

Endo S, Takizawa R, Okuda K, Takada H, Chiba K, Kanehiro H, Ogi H, Yamashita R, Date T (2005) Concentration of polychlorinated biphenyls (PCBs) in beached resin pellets: variability among individual particles and regional differences. Mar Pollut Bull 50:1103-1114. https:// doi.org/10.1016/j.marpolbul.2005.04.030

Engler RE (2012) The complex interaction between marine debris and toxic chemicals in the ocean. Environ Sci Technol 46:12302-12315. https://doi.org/10.1021/es3027105

European Commission (2006) Commission Regulation (EC) No 1881/2006 of 19 December 2006 setting maximum levels for certain contaminants in foodstuffs (Text with EEA relevance) 2006, 5-24

Fair PA, Stavros HC, Mollenhauer MAM, Dewitt JC, Henry N, Kannan K, Yun SH, Bossart GD, Keil DE, Peden-Adams MM (2012) Immune function in female B6C3F1 mice is modulated by DE-71, a commercial polybrominated diphenyl ether mixture. J Immunotoxicol. https://doi. org/10.3109/1547691X.2011.643418

FAO (2017) 2017. Microplastics in fisheries and aquaculture: status of knowledge on their occurrence and implications for aquatic organisms and food safety, FAO Fisheries and Aquaculture Technical Paper 615

FAO/WHO (2009) BISPHENOL A ( BPA ) - current state of knowledge and future actions by WHO and FAO. WHO, pp 1-6

Faroon OM, Keith LS, Smith-Simon C, De Rosa CT (2003) Concise international chemical assessment document 55: polychlorinated biphenyls: human health aspects. IPCS Concise Int Chem Assess Doc

Fisner M, Majer A, Taniguchi S, Bícego M, Turra A, Gorman D (2017) Colour spectrum and resin-type determine the concentration and composition of Polycyclic Aromatic Hydrocarbons (PAHs) in plastic pellets. Mar Pollut Bull. https://doi.org/10.1016/j.marpolbul.2017.06.072

Frias JPGL, Sobral P, Ferreira AM (2010) Organic pollutants in microplastics from two beaches of the Portuguese coast. Mar Pollut Bull 60:1988-1992. https://doi.org/10.1016/j. marpolbul.2010.07.030

Gauquie J, Devriese L, Robbens J, De Witte B (2015) A qualitative screening and quantitative measurement of organic contaminants on different types of marine plastic debris. Chemosphere 138:348-356. https://doi.org/10.1016/j.chemosphere.2015.06.029

GESAMP (2015) Sources, fate and effects of microplastics in the marine environment: a global assessment. Reports Stud. GESAMP

GESAMP (2016) Sources, fate and effects of microplastics in the marine environment: part two of a global assessment. Reports Stud. GESAMP

Geyer R, Jambeck JR, Law KL (2017) Production, use, and fate of all plastics ever made. Sci Adv 3:e1700782. https://doi.org/10.1126/sciadv.1700782

Granby K, Rainieri S, Rasmussen RR, Kotterman MJJ, Sloth JJ, Cederberg TL, Barranco A, Marques A, Larsen BK (2018) The influence of microplastics and halogenated contaminants in feed on toxicokinetics and gene expression in European seabass (Dicentrarchus labrax). Environ Res. https://doi.org/10.1016/j.envres.2018.02.035

Gündoğdu S (2018) Contamination of table salts from Turkey with microplastics. Food Addit Contam - Part A Chem Anal Control Expo Risk Assess. https://doi.org/10.1080/1944004 9.2018.1447694

Güven O, Gökdağ K, Jovanović B, Kıdeyş AE (2017) Microplastic litter composition of the Turkish territorial waters of the Mediterranean Sea, and its occurrence in the gastrointestinal tract of fish. Environ Pollut. https://doi.org/10.1016/j.envpol.2017.01.025 
Heinrich P, Braunbeck T (2019) Bioavailability of microplastic-bound pollutants in vitro: the role of adsorbate lipophilicity and surfactants. Comp Biochem Physiol Part - C Toxicol Pharmacol 221:59-67. https://doi.org/10.1016/j.cbpc.2019.03.012

Heskett M, Takada H, Yamashita R, Yuyama M, Ito M, Geok YB, Ogata Y, Kwan C, Heckhausen A, Taylor H, Powell T, Morishige C, Young D, Patterson H, Robertson B, Bailey E, Mermoz J (2012) Measurement of persistent organic pollutants (POPs) in plastic resin pellets from remote islands: toward establishment of background concentrations for International Pellet Watch. Mar Pollut Bull. https://doi.org/10.1016/j.marpolbul.2011.11.004

Hipfner JM, Galbraith M, Tucker S, Studholme KR, Domalik AD, Pearson SF, Good TP, Ross PS, Hodum P (2018) Two forage fishes as potential conduits for the vertical transfer of microfibres in Northeastern Pacific Ocean food webs. Environ Pollut. https://doi.org/10.1016/j. envpol.2018.04.009

Hirai H, Takada H, Ogata Y, Yamashita R, Mizukawa K, Saha M, Kwan C, Moore C, Gray H, Laursen D, Zettler ER, Farrington JW, Reddy CM, Peacock EE, Ward MW (2011) Organic micropollutants in marine plastics debris from the open ocean and remote and urban beaches. Mar Pollut Bull 62:1683-1692. https://doi.org/10.1016/j.marpolbul.2011.06.004

Holmes LA, Turner A, Thompson RC (2012) Adsorption of trace metals to plastic resin pellets in the marine environment. Environ Pollut 160:42-48. https://doi.org/10.1016/j.envpol.2011.08.052

Holmes LA, Turner A, Thompson RC (2014) Interactions between trace metals and plastic production pellets under estuarine conditions. Mar Chem 167:25-32. https://doi.org/10.1016/j. marchem.2014.06.001

Horn D, Miller M, Anderson S, Steele C (2019) Microplastics are ubiquitous on California beaches and enter the coastal food web through consumption by Pacific mole crabs. Mar Pollut Bull 139:231-237. https://doi.org/10.1016/j.marpolbul.2018.12.039

Hossain MS, Rahman MS, Uddin MN, Sharifuzzaman SM, Chowdhury SR, Sarker S, Nawaz Chowdhury MS (2020) Microplastic contamination in Penaeid shrimp from the Northern Bay of Bengal. Chemosphere 238:124688. https://doi.org/10.1016/j.chemosphere.2019.124688

Hüffer T, Hofmann T (2016) Sorption of non-polar organic compounds by micro-sized plastic particles in aqueous solution. Environ Pollut 214:194-201. https://doi.org/10.1016/j. envpol.2016.04.018

Hussain N, Jaitley V, Florence AT (2001) Recent advances in the understanding of uptake of microparticulates across the gastrointestinal lymphatics. Adv Drug Deliv Rev 50:107-142. https:// doi.org/10.1016/S0169-409X(01)00152-1

Hutzinger O, Thoma H (1987) Polybrominated dibenzo-p-dioxins and dibenzofurans: the flame retardant issue. Chemosphere. https://doi.org/10.1016/0045-6535(87)90181-0

Iñiguez ME, Conesa JA, Fullana A (2017) Microplastics in Spanish table salt. Sci Rep. https://doi. org/10.1038/s41598-017-09128-x

Jabeen K, Su L, Li J, Yang D, Tong C, Mu J, Shi H (2017) Microplastics and mesoplastics in fish from coastal and fresh waters of China. Environ Pollut 221:141-149. https://doi.org/10.1016/j. envpol.2016.11.055

JECFA (1961) Evaluation of the carcinogenic hazards of food additives. Fifth report of the Joint FAO/WHO Expert Committee on Food Additives, Geneva. WHO Technical Report Series - 220

JECFA (1990) Evaluation of certain food additives and contaminants. Thirty-fifth report of the joint FAO/WHO Expert Committee on Food Additives World Health Organization Technical Report Series 789

JECFA (1995) Application of risk analysis to food standards issues. Report of the Joint FAO/WHO Expert Consultation, Geneva. 13-17 March 1995

JECFA (2001) Pesticide residues in food - 2000. Report of the Joint Meeting of the FAO Panel of Experts on Pesticide Residues in Food and the Environment and the WHO Core Assessment Group. FAO Plant Production and Protection Paper 163, 2001. Pestic. residues food 1-249.

JECFA (2002) Pesticide residues in food - 2002. Report of the Joint Meeting of the FAO Panel of Experts on Pesticide Residues in Food and the Environment and the WHO Core Assessment 
Group on Pesticide Residues. FAO Plant Production and Protection Paper 172, 2002., Pesticide residues in food

JECFA (2006a) Joint FAO/WHO expert committee on food additives. Sixty-fourth meeting Rome, 8-17 February 2005

JECFA (2006b) Evaluation of certain food contaminants. Sixty-fourth report of the Joint FAO/ WHO Expert Committee on Food Additives. WHO Technical Report Series, 930. Available at: http://apps.who.int/food-additives-contaminants-jecfadatabase/chemical.aspx?chemID=4306, World Health Organization - Technical Report Series

JECFA (2006c) Safety evaluation of certain contaminants in food. Prepared by the Sixty-fourth meeting of the Joint FAO/WHO Expert Committee on Food Additives (JECFA)

JECFA (2016) Evaluation of certain food additives and contaminants. Eightieth report of the Joint FAO/WHO Expert Committee on Food Additives, Geneva. WHO technical report series - 995. World Heal. Organ. Rep. Ser

Karami A, Golieskardi A, Ho YB, Larat V, Salamatinia B (2017a) Microplastics in eviscerated flesh and excised organs of dried fish. Sci Rep. https://doi.org/10.1038/s41598-017-05828-6

Karami A, Golieskardi A, Keong Choo C, Larat V, Galloway TS, Salamatinia B (2017b) The presence of microplastics in commercial salts from different countries. Sci Rep. https://doi. org/10.1038/srep46173

Karami A, Golieskardi A, Choo CK, Larat V, Karbalaei S, Salamatinia B (2018) Microplastic and mesoplastic contamination in canned sardines and sprats. Sci Total Environ. https://doi. org/10.1016/j.scitotenv.2017.09.005

Karapanagioti HK, Klontza I (2008) Testing phenanthrene distribution properties of virgin plastic pellets and plastic eroded pellets found on Lesvos island beaches (Greece). Mar Environ Res. https://doi.org/10.1016/j.marenvres.2007.11.005

Karapanagioti HK, Endo S, Ogata Y, Takada H (2011) Diffuse pollution by persistent organic pollutants as measured in plastic pellets sampled from various beaches in Greece. Mar Pollut Bull. https://doi.org/10.1016/j.marpolbul.2010.10.009

Kim JS, Lee HJ, Kim SK, Kim HJ (2018) Global pattern of microplastics (MPs) in commercial food-grade salts: sea salt as an indicator of seawater MP pollution. Environ Sci Technol. https:// doi.org/10.1021/acs.est.8b04180

Klaine SJ, Koelmans AA, Horne N, Carley S, Handy RD, Kapustka L, Nowack B, von der Kammer F (2012) Paradigms to assess the environmental impact of manufactured nanomaterials. Environ Toxicol Chem. https://doi.org/10.1002/etc.733

Kosuth M, Mason SA, Wattenberg EV (2018) Anthropogenic contamination of tap water, beer, and sea salt. PLoS One. https://doi.org/10.1371/journal.pone.0194970

Lee H, Shim WJ, Kwon JH (2014) Sorption capacity of plastic debris for hydrophobic organic chemicals. Sci Total Environ 470-471:1545-1552. https://doi.org/10.1016/j.scitotenv.2013.08.023

Leslie HA, van Velzen MJM, Vethaak AD (2013) Microplastic survey of the Dutch environment: novel data set of microplastics in North Sea sediments, treated wastewater effluents and marine biota. IVM Inst Environ Stud 476:1-30

Li J, Yang D, Li L, Jabeen K, Shi H (2015) Microplastics in commercial bivalves from China. Environ Pollut 207:190-195. https://doi.org/10.1016/j.envpol.2015.09.018

Li J, Qu X, Su L, Zhang W, Yang D, Kolandhasamy P, Li D, Shi H (2016) Microplastics in mussels along the coastal waters of China. Environ Pollut 214:177-184. https://doi.org/10.1016/j. envpol.2016.04.012

Li HX, Ma LS, Lin L, Ni ZX, Xu XR, Shi HH, Yan Y, Zheng GM, Rittschof D (2018a) Microplastics in oysters Saccostrea cucullata along the Pearl River Estuary, China. Environ Pollut 236:619-625. https://doi.org/10.1016/j.envpol.2018.01.083

Li J, Green C, Reynolds A, Shi H, Rotchell JM (2018b) Microplastics in mussels sampled from coastal waters and supermarkets in the United Kingdom. Environ Pollut. https://doi. org/10.1016/j.envpol.2018.05.038

Li J, Zhang K, Zhang H (2018c) Adsorption of antibiotics on microplastics. Environ Pollut. https:// doi.org/10.1016/j.envpol.2018.02.050 
Li Y, Li M, Li Z, Yang L, Liu X (2019) Effects of particle size and solution chemistry on Triclosan sorption on polystyrene microplastic. Chemosphere 231:308-314. https://doi.org/10.1016/j. chemosphere.2019.05.116

Li Q, Feng Z, Zhang T, Ma C, Shi H (2020) Microplastics in the commercial seaweed nori. J Hazard Mater. https://doi.org/10.1016/j.jhazmat.2020.122060

Liebezeit G, Liebezeit E (2013) Non-pollen particulates in honey and sugar. Food Addit Contam Part A Chem Anal Control Expo Risk Assess. https://doi.org/10.1080/19440049.2013.843025

Liebezeit G, Liebezeit E (2014) Synthetic particles as contaminants in German beers. Food Addit Contam - Part A Chem Anal Control Expo Risk Assess. https://doi.org/10.1080/1944004 9.2014.945099

Lithner D, Larsson A, Dave G (2011) Environmental and health hazard ranking and assessment of plastic polymers based on chemical composition. Sci Total Environ 409:3309-3324. https:// doi.org/10.1016/j.scitotenv.2011.04.038

Llorca M, Schirinzi G, Martínez M, Barceló D, Farré M (2018) Adsorption of perfluoroalkyl substances on microplastics under environmental conditions. Environ Pollut 235:680-691. https:// doi.org/10.1016/j.envpol.2017.12.075

Lusher AL, McHugh M, Thompson RC (2013) Occurrence of microplastics in the gastrointestinal tract of pelagic and demersal fish from the English Channel. Mar Pollut Bull 67:94-99. https:// doi.org/10.1016/j.marpolbul.2012.11.028

Lusher AL, O'Donnell C, Officer R, O'Connor I (2016) Microplastic interactions with North Atlantic mesopelagic fish. ICES J Mar Sci. https://doi.org/10.1093/icesjms/fsv241

Lusher AL, Welden NA, Sobral P, Cole M (2017) Sampling, isolating and identifying microplastics ingested by fish and invertebrates. Anal Methods 9:1346-1360. https://doi.org/10.1039/ C6AY02415G

Ma Y, Huang A, Cao S, Sun F, Wang L, Guo H, Ji R (2016) Effects of nanoplastics and microplastics on toxicity, bioaccumulation, and environmental fate of phenanthrene in fresh water. Environ Pollut 219:166-173. https://doi.org/10.1016/j.envpol.2016.10.061

Ma Y, Liu H, Wu J, Yuan L, Wang Y, Du X, Wang R, Marwa PW, Petlulu P, Chen X, Zhang H (2019) The adverse health effects of bisphenol A and related toxicity mechanisms. Environ Res. https://doi.org/10.1016/j.envres.2019.108575

Mathalon A, Hill P (2014) Microplastic fibers in the intertidal ecosystem surrounding Halifax Harbor, Nova Scotia. Mar Pollut Bull 81:69-79. https://doi.org/10.1016/j. marpolbul.2014.02.018

Mato Y, Isobe T, Takada H, Kanehiro H, Ohtake C, Kaminuma T (2001) Plastic resin pellets as a transport medium for toxic chemicals in the marine environment. Environ Sci Technol 35:318-324. https://doi.org/10.1021/es0010498

Miranda de, D. A., \& de Carvalho-Souza, G. F (2016) Are we eating plastic-ingesting fish? Mar Pollut Bull. https://doi.org/10.1016/j.marpolbul.2015.12.035

Mizukawa K, Takada H, Ito M, Geok YB, Hosoda J, Yamashita R, Saha M, Suzuki S, Miguez C, Frias J, Antunes JC, Sobral P, Santos I, Micaelo C, Ferreira AM (2013) Monitoring of a wide range of organic micropollutants on the Portuguese coast using plastic resin pellets. Mar Pollut Bull 70:296-302. https://doi.org/10.1016/j.marpolbul.2013.02.008

Monti DM, Guarnieri D, Napolitano G, Piccoli R, Netti P, Fusco S, Arciello A (2015) Biocompatibility, uptake and endocytosis pathways of polystyrene nanoparticles in primary human renal epithelial cells. J Biotechnol. https://doi.org/10.1016/j.jbiotec.2014.11.004

Muirhead EK, Skillman AD, Hook SE, Schultz IR (2006) Oral Exposure of PBDE-47 in Fish: Toxicokinetics and Reproductive Effects in Japanese Medaka (Oryzias latipes) and Fathead Minnows (Pimephales promelas). Environ Sci Technol 40:523-528. https://doi.org/10.1021/ es0513178

Müller A, Becker R, Dorgerloh U, Simon F-G, Braun U (2018) The effect of polymer aging on the uptake of fuel aromatics and ethers by microplastics. Environ Pollut 240:639-646. https://doi. org/10.1016/j.envpol.2018.04.127 
Murray F, Cowie PR (2011) Plastic contamination in the decapod crustacean Nephrops norvegicus (Linnaeus, 1758). Mar Pollut Bull 62:1207-1217. https://doi.org/10.1016/j. marpolbul.2011.03.032

Nadal MA, Alomar C, Deudero S (2016) High levels of microplastic ingestion by the semipelagic fish bogue Boops boops (L.) around the Balearic Islands. Environ Pollut. https://doi. org/10.1016/j.envpol.2016.04.054

Naji A, Nuri M, Vethaak AD (2018) Microplastics contamination in molluscs from the northern part of the Persian Gulf. Environ Pollut. https://doi.org/10.1016/j.envpol.2017.12.046

Napper IE, Bakir A, Rowland SJ, Thompson RC (2015) Characterisation, quantity and sorptive properties of microplastics extracted from cosmetics. Mar Pollut Bull 99:178-185. https://doi. org/10.1016/j.marpolbul.2015.07.029

Neves D, Sobral P, Ferreira JL, Pereira T (2015) Ingestion of microplastics by commercial fish off the Portuguese coast. Mar Pollut Bull 101:119-126. https://doi.org/10.1016/j. marpolbul.2015.11.008

Nielsen E, Østergaard G, Inger Thorup O, Ladefoged O, Jelnes JE (2000) Toxicological evaluation and limit values for nonylphenol, nonylphenol ethoxylates, tricresyl phosphates and benzoic acid. Inst Food Saf Toxicol - Danish Vet Food Adm 43

O'Connor IA, Golsteijn L, Hendriks AJ (2016) Review of the partitioning of chemicals into different plastics: consequences for the risk assessment of marine plastic debris. Mar Pollut Bull 113:17-24. https://doi.org/10.1016/j.marpolbul.2016.07.021

Ogata Y, Takada H, Mizukawa K, Hirai H, Iwasa S, Endo S, Mato Y, Saha M, Okuda K, Nakashima A, Murakami M, Zurcher N, Booyatumanondo R, Zakaria MP, Dung LQ, Gordon M, Miguez C, Suzuki S, Moore C, Karapanagioti HK, Weerts S, McClurg T, Burres E, Smith W, Van Velkenburg M, Lang JS, Lang RC, Laursen D, Danner B, Stewardson N, Thompson RC (2009) International Pellet Watch: Global monitoring of persistent organic pollutants (POPs) in coastal waters. 1. Initial phase data on PCBs, DDTs, and HCHs. Mar Pollut Bull 58:1437-1446. https://doi.org/10.1016/j.marpolbul.2009.06.014

Ory NC, Sobral P, Ferreira JL, Thiel M (2017) Amberstripe scad Decapterus muroadsi (Carangidae) fish ingest blue microplastics resembling their copepod prey along the coast of Rapa Nui (Easter Island) in the South Pacific subtropical gyre. Sci Total Environ. https://doi. org/10.1016/j.scitotenv.2017.01.175

Peters CA, Thomas PA, Rieper KB, Bratton SP (2017) Foraging preferences influence microplastic ingestion by six marine fish species from the Texas Gulf Coast. Mar Pollut Bull. https://doi. org/10.1016/j.marpolbul.2017.06.080

Petit A, Catelas I, Antoniou J, Zukor DJ, Huk OL (2002) Differential apoptotic response of J774 macrophages to alumina and ultra-high-molecular-weight polyethylene particles. J Orthop Res 20:9-15. https://doi.org/10.1016/S0736-0266(01)00077-8

Phuong NN, Zalouk-Vergnoux A, Kamari A, Mouneyrac C, Amiard F, Poirier L, Lagarde F (2018) Quantification and characterization of microplastics in blue mussels (Mytilus edulis): protocol setup and preliminary data on the contamination of the French Atlantic coast. Environ Sci Pollut Res 25:6135-6144. https://doi.org/10.1007/s11356-017-8862-3

Pivokonsky M, Cermakova L, Novotna K, Peer P, Cajthaml T, Janda V (2018) Occurrence of microplastics in raw and treated drinking water. Sci Total Environ. https://doi.org/10.1016/j. scitotenv.2018.08.102

Pocar P, Fischer B, Klonisch T, Hombach-Klonisch S (2005) Molecular interactions of the aryl hydrocarbon receptor and its biological and toxicological relevance for reproduction. Reproduction 129:379-389. https://doi.org/10.1530/rep.1.00294

Qu X, Su L, Li H, Liang M, Shi H (2018) Assessing the relationship between the abundance and properties of microplastics in water and in mussels. Sci Total Environ 621:679-686. https://doi. org/10.1016/j.scitotenv.2017.11.284

Ragusa A, Svelato A, Santacroce C, Catalano P, Notarstefano V, Carnevali O, Papa F, Rongioletti MCA, Baiocco F, Draghi S, D’Amore E, Rinaldo D, Matta M, Giorgini E (2021) Plasticenta: 
first evidence of microplastics in human placenta. Environ Int. https://doi.org/10.1016/j. envint.2020.106274

Rani M, Shim WJ, Han GM, Jang M, Song YK, Hong SH (2017) Benzotriazole-type ultraviolet stabilizers and antioxidants in plastic marine debris and their new products. Sci Total Environ. https://doi.org/10.1016/j.scitotenv.2016.11.033

Renzi M, Blašković A (2018) Litter \& microplastics features in table salts from marine origin: Italian versus Croatian brands. Mar Pollut Bull. https://doi.org/10.1016/j.marpolbul.2018.06.065

Renzi M, Guerranti C, Blašković A (2018) Microplastic contents from maricultured and natural mussels. Mar Pollut Bull. https://doi.org/10.1016/j.marpolbul.2018.04.035

Rios LM, Moore C, Jones PR (2007) Persistent organic pollutants carried by synthetic polymers in the ocean environment. Mar Pollut Bull 54:1230-1237. https://doi.org/10.1016/j. marpolbul.2007.03.022

Rios LM, Jones PR, Moore C, Narayan UV (2010) Quantitation of persistent organic pollutants adsorbed on plastic debris from the Northern Pacific Gyre's "eastern garbage patch". J Environ Monit. https://doi.org/10.1039/c0em00239a

Rochester JR (2013) Bisphenol A and human health: a review of the literature. Reprod Toxicol. https://doi.org/10.1016/j.reprotox.2013.08.008

Rochman CM, Hoh E, Kurobe T, Teh SJ (2013) Ingested plastic transfers hazardous chemicals to fish and induces hepatic stress. Sci Rep 3:1-7. https://doi.org/10.1038/srep03263

Rochman CM, Lewison RL, Eriksen M, Allen H, Cook AM, Teh SJ (2014) Polybrominated diphenyl ethers (PBDEs) in fish tissue may be an indicator of plastic contamination in marine habitats. Sci Total Environ. https://doi.org/10.1016/j.scitotenv.2014.01.058

Rochman CM, Tahir A, Williams SL, Baxa DV, Lam R, Miller JT, Teh FC, Werorilangi S, Teh SJ (2015) Anthropogenic debris in seafood: plastic debris and fibers from textiles in fish and bivalves sold for human consumption. Sci Rep. https://doi.org/10.1038/srep14340

Rummel CD, Löder MGJ, Fricke NF, Lang T, Griebeler EM, Janke M, Gerdts G (2016) Plastic ingestion by pelagic and demersal fish from the North Sea and Baltic Sea. Mar Pollut Bull 102:134-141. https://doi.org/10.1016/j.marpolbul.2015.11.043

Ryan PG, Connell AD, Gardner BD (1988) Marine pollution bulletin plastic ingestion and PCBs in seabirds: is there a relationship? Mar Pollut Bull 19:174-176

Safe SH (1986) Comparative toxicology and mechanism of action of polychlorinated dibenzo-pdioxins and dibenzofurans. Annu Rev Pharmacol Toxicol 26:371-399. https://doi.org/10.1146/ annurev.pharmtox.26.1.371

Safe S, Bandiera S, Sawyer T (1985) PCBs: structure-function relationships and mechanism of action. Environ Health Perspect 60:47-56. https://doi.org/10.1289/ehp.856047

Sakai S, Urano S, Takatsuki H (2000) Leaching behavior of PCBs and PCDDs/DFs from some waste materials. Waste Manag. https://doi.org/10.1016/S0956-053X(99)00316-5

Santana MFM, Ascer LG, Custódio MR, Moreira FT, Turra A (2016) Microplastic contamination in natural mussel beds from a Brazilian urbanized coastal region: rapid evaluation through bioassessment. Mar Pollut Bull 106:183-189. https://doi.org/10.1016/j.marpolbul.2016.02.074

Savoca MS, Wohlfeil ME, Ebeler SE, Nevitt GA (2016) Marine plastic debris emits a keystone infochemical for olfactory foraging seabirds. Sci Adv 2:1-9. https://doi.org/10.1126/ sciadv. 1600395

Schirinzi GF, Pérez-Pomeda I, Sanchís J, Rossini C, Farré M, Barceló D (2017) Cytotoxic effects of commonly used nanomaterials and microplastics on cerebral and epithelial human cells. Environ Res 159:579-587. https://doi.org/10.1016/j.envres.2017.08.043

Scientific Committee on Food (2002a) Opinion of the Scientific Committee on Food on Bisphenol A. SCF/CS/PM/3936 Final. Eur Comm Heal Consum Prot Dir

Scientific Committee on Food (2002b) Opinion of the Scientific Committee on Food on the risks to human health of Polycyclic Aromatic Hydrocarbons in Food SCF/CS/CNTM/PAH/29 ADD1. Annex

Seth CK, Shriwastav A (2018) Contamination of Indian sea salts with microplastics and a potential prevention strategy. Environ Sci Pollut Res. https://doi.org/10.1007/s11356-018-3028-5 
Silva-Cavalcanti JS, Silva JDB, de França EJ, de Araújo MCB, Gusmão F (2017) Microplastics ingestion by a common tropical freshwater fishing resource. Environ Pollut 221:218-226. https://doi.org/10.1016/j.envpol.2016.11.068

Soares A, Guieysse B, Jefferson B, Cartmell E, Lester JN (2008) Nonylphenol in the environment: a critical review on occurrence, fate, toxicity and treatment in wastewaters. Environ Int. https:// doi.org/10.1016/j.envint.2008.01.004

Suhrhoff TJ, Scholz-Böttcher BM (2016) Qualitative impact of salinity, UV radiation and turbulence on leaching of organic plastic additives from four common plastics - A lab experiment. Mar Pollut Bull. https://doi.org/10.1016/j.marpolbul.2015.11.054

Takada H, Mato Y, Endo S, Yamashita R, Zakaria MP (2006) Pellet watch : global monitoring of persistent organic pollutants (POPs) using beached plastic resin pellets. English

Tanaka K, Takada H (2016) Microplastic fragments and microbeads in digestive tracts of planktivorous fish from urban coastal waters. Sci Rep. https://doi.org/10.1038/srep34351

Tanaka K, Takada H, Yamashita R, Mizukawa K, Fukuwaka MA, Watanuki Y (2013) Accumulation of plastic-derived chemicals in tissues of seabirds ingesting marine plastics. Mar Pollut Bull 69:219-222. https://doi.org/10.1016/j.marpolbul.2012.12.010

Tanaka K, Takada H, Ikenaka Y, Nakayama SMM, Ishizuka M (2020) Occurrence and concentrations of chemical additives in plastic fragments on a beach on the island of Kauai. Hawaii Mar Pollut Bull. https://doi.org/10.1016/j.marpolbul.2019.110732

Teuten EL, Saquing JM, Knappe DRU, Barlaz MA, Jonsson S, Björn A, Rowland SJ, Thompson RC, Galloway TS, Yamashita R, Ochi D, Watanuki Y, Moore C, Viet PH, Tana TS, Prudente M, Boonyatumanond R, Zakaria MP, Akkhavong K, Ogata Y, Hirai H, Iwasa S, Mizukawa K, Hagino Y, Imamura A, Saha M, Takada H (2009) Transport and release of chemicals from plastics to the environment and to wildlife. Philos Trans R Soc B Biol Sci 364:2027-2045. https:// doi.org/10.1098/rstb.2008.0284

Thushari GGN, Senevirathna JDM, Yakupitiyage A, Chavanich S (2017) Effects of microplastics on sessile invertebrates in the eastern coast of Thailand: an approach to coastal zone conservation. Mar Pollut Bull 124:349-355. https://doi.org/10.1016/j.marpolbul.2017.06.010

US EPA (1992) Plastic pellets in the aquatic environment: sources and recommendations. United States Environmental Protection Agency

USEPA (2010) Nonylphenol (NP) and Nonylphenol Ethoxylates (NPEs) Action Plan. U.S. Environmental Protection Agency

Van Cauwenberghe L, Janssen CR (2014) Microplastics in bivalves cultured for human consumption. Environ Pollut. https://doi.org/10.1016/j.envpol.2014.06.010

Van Cauwenberghe L, Claessens M, Vandegehuchte MB, Janssen CR (2015) Microplastics are taken up by mussels (Mytilus edulis) and lugworms (Arenicola marina) living in natural habitats. Environ Pollut 199:10-17. https://doi.org/10.1016/j.envpol.2015.01.008

Van den Berg M, Birnbaum LS, Denison M, De Vito M, Farland W, Feeley M, Fiedler H, Hakansson H, Hanberg A, Haws L, Rose M, Safe S, Schrenk D, Tohyama C, Tritscher A, Tuomisto J, Tysklind M, Walker N, Peterson RE (2006) The 2005 World Health Organization reevaluation of human and mammalian toxic equivalency factors for dioxins and dioxin-like compounds. Toxicol Sci 93:223-241. https://doi.org/10.1093/toxsci/kfl055

Vandermeersch G, Van Cauwenberghe L, Janssen CR, Marques A, Granby K, Fait G, Kotterman MJJ, Diogène J, Bekaert K, Robbens J, Devriese L (2015) A critical view on microplastic quantification in aquatic organisms. Environ Res 143:46-55. https://doi.org/10.1016/j. envres.2015.07.016

Velzeboer I, Kwadijk CJAF, Koelmans AA (2014) Strong sorption of PCBs to nanoplastics, microplastics, carbon nanotubes, and fullerenes. Environ Sci Technol. https://doi.org/10.1021/ es405721v

Vethaak AD, Lahr J, Schrap SM, Belfroid AC, Rijs GBJ, Gerritsen A, de Boer J, Bulder AS, Grinwis GCM, Kuiper RV, Legler J, Murk TAJ, Peijnenburg W, Verhaar HJM, de Voogt P (2005) An integrated assessment of estrogenic contamination and biological effects in the 
aquatic environment of The Netherlands. Chemosphere 59:511-524. https://doi.org/10.1016/j. chemosphere.2004.12.053

Wang W, Wang J (2018) Comparative evaluation of sorption kinetics and isotherms of pyrene onto microplastics. Chemosphere. https://doi.org/10.1016/j.chemosphere.2017.11.078

Wang F, Shih KM, Li XY (2015) The partition behavior of perfluorooctanesulfonate (PFOS) and perfluorooctanesulfonamide (FOSA) on microplastics. Chemosphere 119:841-847. https://doi. org/10.1016/j.chemosphere.2014.08.047

Wang F, Wang F, Zeng EY (2018a) Sorption of toxic chemicals on microplastics. In: Microplastic contamination in aquatic environments. Elsevier, pp 225-247. https://doi.org/10.1016/B978-0 -12-813747-5.00007-2

Wang Z, Chen M, Zhang L, Wang K, Yu X, Zheng Z, Zheng R (2018b) Sorption behaviors of phenanthrene on the microplastics identified in a mariculture farm in Xiangshan Bay, southeastern China. Sci Total Environ 628-629:1617-1626. https://doi.org/10.1016/j.scitotenv.2018.02.146

Wang J, Liu X, Liu G, Zhang Z, Wu H, Cui B, Bai J, Zhang W (2019) Size effect of polystyrene microplastics on sorption of phenanthrene and nitrobenzene. Ecotoxicol Environ Saf 173:331-338. https://doi.org/10.1016/j.ecoenv.2019.02.037

Wardrop P, Shimeta J, Nugegoda D, Morrison PD, Miranda A, Tang M, Clarke BO (2016) Chemical pollutants Sorbed to ingested microbeads from personal care products accumulate in fish. Environ Sci Technol 50:4037-4044. https://doi.org/10.1021/acs.est.5b06280

Webster L, Roose P, Bersuder P, Kotterman MJJ, Haarich M, Vorkamp K (2013) Determination of polychlorinated biphenyls (PCBs) in sediment and biota. ICES Tech Mar Environ Sci 53

Wei X-F, Linde E, Hedenqvist MS (2019) Plasticiser loss from plastic or rubber products through diffusion and evaporation. npj Mater Degrad. https://doi.org/10.1038/s41529-019-0080-7

WHO (2019) Microplastics in Drinking-Water; Licence: CC BY-NC-SA 3.0 IGO: World Health Organization: Geneva

Wick P, Malek A, Manser P, Meili D, Maeder-Althaus X, Diener L, Diener PA, Zisch A, Krug HF, Von Mandach U (2010) Barrier capacity of human placenta for nanosized materials. Environ Health Perspect 118:432-436. https://doi.org/10.1289/ehp.0901200

Yamashita R, Takada H, Fukuwaka MA, Watanuki Y (2011) Physical and chemical effects of ingested plastic debris on short-tailed shearwaters, Puffinus tenuirostris, in the North Pacific Ocean. Mar Pollut Bull 62:2845-2849. https://doi.org/10.1016/j.marpolbul.2011.10.008

Yang D, Shi H, Li L, Li J, Jabeen K, Kolandhasamy P (2015) Microplastic pollution in table salts from China. Environ Sci Technol. https://doi.org/10.1021/acs.est.5b03163

Yogui GT, Sericano JL (2009) Polybrominated diphenyl ether flame retardants in the U.S. marine environment: a review. Environ Int 35:655-666. https://doi.org/10.1016/j.envint.2008.11.001

Yoo JW, Doshi N, Mitragotri S (2011) Adaptive micro and nanoparticles: temporal control over carrier properties to facilitate drug delivery. Adv Drug Deliv Rev 63:1247-1256. https://doi. org/10.1016/j.addr.2011.05.004

Zakeri M, Naji A, Akbarzadeh A, Uddin S (2020) Microplastic ingestion in important commercial fish in the southern Caspian Sea. Mar Pollut Bull. https://doi.org/10.1016/j. marpolbul.2020.111598

Zhan Z, Wang J, Peng J, Xie Q, Huang Y, Gao Y (2016) Sorption of 3,3',4,4'-tetrachlorobiphenyl by microplastics: a case study of polypropylene. Mar Pollut Bull 110:559-563. https://doi. org/10.1016/j.marpolbul.2016.05.036

Zhang X, Zheng M, Wang L, Lou Y, Shi L, Jiang S (2018) Sorption of three synthetic musks by microplastics. Mar Pollut Bull 126:606-609. https://doi.org/10.1016/j.marpolbul.2017.09.025

Zuo LZ, Li HX, Lin L, Sun YX, Diao ZH, Liu S, Zhang ZY, Xu XR (2019) Sorption and desorption of phenanthrene on biodegradable poly(butylene adipate co-terephthalate) microplastics. Chemosphere. https://doi.org/10.1016/j.chemosphere.2018.09.173 
Open Access This chapter is licensed under the terms of the Creative Commons Attribution 4.0 International License (http://creativecommons.org/licenses/by/4.0/), which permits use, sharing, adaptation, distribution and reproduction in any medium or format, as long as you give appropriate credit to the original author(s) and the source, provide a link to the Creative Commons license and indicate if changes were made.

The images or other third party material in this chapter are included in the chapter's Creative Commons license, unless indicated otherwise in a credit line to the material. If material is not included in the chapter's Creative Commons license and your intended use is not permitted by statutory regulation or exceeds the permitted use, you will need to obtain permission directly from the copyright holder. 